\title{
Influence of in vitro supplementation with lipids from conventional and Alpine milk on fatty acid distribution and cell growth of HT-29 cells
}

\author{
Christian Degen ${ }^{1}$, Alfred Lochner ${ }^{1}$, Sylvia Keller ${ }^{1}$, Katrin Kuhnt ${ }^{1}$, Sven Dänicke ${ }^{2}$ and Gerhard Jahreis ${ }^{* *}$
}

\begin{abstract}
Background: To date, the influence of milk and dairy products on carcinogenesis remains controversial. However, lipids of ruminant origin such as conjugated linoleic acids (CLA) are known to exhibit beneficial effects in vitro and in vivo. The aim of the present study was to determine the influence of milk lipids of different origin and varying quality presenting as free fatty acid (FFA) solutions on cellular fatty acid distribution, cellular viability, and growth of human colon adenocarcinoma cells (HT-29).

Methods: FAME of conventional and Alpine milk lipids $\left(\mathrm{ML}_{\mathrm{con}}, \mathrm{ML}_{\mathrm{alp}}\right)$ and cells treated with FFA derivatives of milk lipids were analyzed by means of GC-FID and $\mathrm{Ag}^{+}-\mathrm{HPLC}$. Cellular viability and growth of the cells were determined by means of CellTiter-Blue ${ }^{\circledR}$-assay and DAPI-assay (4',6-diamidino-2-phenylindole dihydrochloride), respectively.

Results: Supplementation with milk lipids significantly decreased viability and growth of HT-29 cells in a dose- and time-dependent manner. MLalp showed a lower SFA/MUFA ratio, a 8 fold increased CLA content, and different CLA profile compared to $\mathrm{ML}_{\text {con }}$ but did not demonstrate additional growth-inhibitory effects. In addition, total concentration and fatty acid distribution of cellular lipids were altered. In particular, treatment of the cells yielded highest amounts of two types of milk specific major fatty acids ( $\mu \mathrm{g} \mathrm{FA} / \mathrm{mg}$ cellular protein) after $8 \mathrm{~h}$ of incubation compared to 24 h; $200 \mu \mathrm{M}$ of $\mathrm{ML}_{\text {con }}$ (C16:0, $206 \pm$ 43), $200 \mu \mathrm{M}$ of MLalp (C18:1 C9, (223 \pm 19). Vaccenic acid (C18:1 t11) contained in milk lipids was converted to $c 9, t 11-C L A$ in HT-29 cells. Notably, the ratio of $t 11, c 13-C L A / t 7, c 9-C L A$, a criterion for pasture feeding of the cows, was significantly changed after incubation for $8 \mathrm{~h}$ with lipids from $\mathrm{ML}_{\mathrm{alp}}$ (3.6 - 4.8), compared to lipids from $\mathrm{ML}_{\mathrm{con}}(0.3$ - 0.6).

Conclusions: Natural lipids from conventional and Alpine milk showed similar growth inhibitory effects. However, different changes in cellular lipid composition suggested a milk lipid-depending influence on cell sensitivity. It is expected that similar changes may also be evident in other cell lines. To our knowledge, this is the first study showing a varied impact of complex milk lipids on fatty acid distribution in a colon cancer cell line.
\end{abstract}

Keywords: Conjugated linoleic acid, milk lipids, cellular lipid distribution, cancer cells, HT-29

\section{Background}

The incidence for colon cancer world-wide is increasing; the Western-style diet in particular is considered to be one of the main risk factors involved in colon cancer development [1]. In general, the Western-style diet associated with a high fat intake is considered to be an adverse factor. However, the composition of dietary fat

\footnotetext{
* Correspondence: b6jage@uni-jena.de

${ }^{1}$ Friedrich-Schiller-University, Institute of Nutrition, Dept. of Nutritional

Physiology, Dornburger Str. 24, Jena, Germany

Full list of author information is available at the end of the article
}

is decisive for an assessment of its nutritional value and its role in the incidence of cancer [2]. The nutritional role of milk, dairy products and meat of ruminant origin also displays this controversy since on the one hand, these products contain potent chemopreventive and anticarcinogenic compounds such as branched-chain fatty acids (BCFA), phospholipids, ether lipids, vitamin $\mathrm{D}$, and conjugated linoleic acid (CLA) which play a protective role in colorectal cancer $[3,4]$. On the other hand, milk lipids contain high amounts of saturated fatty acids (SFA) that are associated with an increased

\section{C) Biomed Central}


risk of nutrition-related diseases [5]. However, recent data supports a role of dietary fat of animal origin with an increased risk of breast and pancreatic cancer [6,7].

Concerning CLA, however, no significant association between dietary intake and risk of breast cancer has been found according to a recent study [8]. CLA from ruminant origin exhibit an increased potential for anticarcinogenic activity in vitro and in vivo [9]. CLA (C18:2; $c / t, t / c, c / c, t / t)$ display a high variation of positional and geometrical isomers with conjugated double bonds depending on the ruminant species, season and the type of feeding. C9,t11-CLA is the main dietary isomer (90\%). In cows, extensive feeding on herbs and pasture with a high composition of PUFA (polyunsaturated fatty acid) increased total CLA amount and CLA precursor such as C18:1 t11 (VA, vaccenic acid) in milk fat, and generated different isomers such as $t 11, c 13-C L A$ [10]. An intensive feeding diet leads to lower CLA content [11]. To date, only a few studies have investigated the impact of CLA in its natural form, e.g. in butter fat or beef tallow in vivo [12-14], and in milk fat or beef extracts in vitro on cancer [15-17]. Investigations of nutritional substances relevant to health and diseases in in vitro models allow a better understanding of potential effects and the related molecular mechanisms. Remarkably, none of the in vitro studies examined the incorporation and metabolism of lipid mixtures into cell lipids to determine whether growth inhibition is associated with fatty acid (FA) distribution. Dietary PUFA, including CLA, have been shown to be effective inducers of cell death [18]. Thus, in this study, we examined the effects of Alpine milk fat naturally enriched in CLA and other PUFA in comparison to conventional milk fat on viability, growth and cellular FA distribution of highly transformed HT-29 colon adenocarcinoma cells. This in vitro study model allows an examination of the positive or negative influence of a complete FA spectrum on human health. By supplementation with mixtures containing $c 9, t 11-$ CLA and other PUFA as anticarcinogenic compounds, this study aims to clarify the effects of these lipids on colon cancer cells. Previous study models employed these lipids as pure single isomers. In contrast, herein, complex milk lipids from two different origins and of varying quality were used to examine their degree and relevant mode of action.

\section{Methods}

\section{Milk samples and fatty acid analysis}

During the interventional trial, conventional milk lipids $\left(\mathrm{ML}_{\mathrm{con}}\right.$, Braunschweig, Germany) were derived from German Holstein cows receiving a diet consisting of $50 \%$ concentrate and 50\% roughage [19]. Alpine milk lipids $\left(\mathrm{ML}_{\mathrm{alp}}\right.$, Switzerland) were prepared from the milk of Simmental $x$ Red Holstein cows kept on summer pasture without concentrate in the Swiss Alps. At least 8 milk lipid samples from each breed were pooled to obtain sufficient free fatty acid (FFA) derivative sample material for the in vitro investigation in HT-29 cells. FA distribution of the samples was analyzed after transesterfication of total milk lipids to fatty acid methylesters (FAME) using methanolic sodium methylate $0.5 \mathrm{~N}$ at room temperature for $20 \mathrm{~min}$. The FA analysis of total FAME including the distribution of cis/trans-C18:1 isomers required two GC methods. Firstly, FA distribution of four to twenty-six chain carbon atoms including total CLA was analyzed using a fused-silica capillary column with medium polarity (DB-225 MS: $60 \mathrm{~m} \times 0.25 \mathrm{~mm}$ i. d. with $0.25 \mu \mathrm{m}$ film thickness; Agilent Technologies, USA) as described previously [20]. Secondly, a fusedsilica capillary column with high polarity (CP-select: 200 $\mathrm{m} \times 0.25 \mathrm{~mm}$ i.d. with $0.25 \mu \mathrm{m}$ film thickness; Varian, Netherlands) was used to separate octadecenoic acid methylesters with cis- and trans-configuration under isothermal conditions at $176^{\circ} \mathrm{C}$. The temperature of the injector and the flame ionization detector was set at $260^{\circ} \mathrm{C}$ and $270^{\circ} \mathrm{C}$ for both GC programs, respectively. Hydrogen was used as a carrier gas. Evaluation of the chromatograms was completed according to the retention time of known standards with GC solution software (GC-solution version 2.3 from Shimadzu, Kyoto, Japan). FAME standards for GC analysis were received from CPS Chemie (Aachen, Germany), Nu-Chek Prep (Elysian, USA), Sigma (Steinheim, Germany), and Supelco (Taufkirchen, Germany). Additionally, silver ion-HPLC $\left(\mathrm{Ag}^{+}\right.$-HPLC) was used to separate FAME of CLA isomers as described previously [21]. In brief, LC10AHPLC (Shimadzu, Kyoto, Japan) with three silver ionimpregnated columns (Chrompack ChromSpher 5 Lipids; each: $250 \mathrm{~mm} \times 4.6 \mathrm{~mm}$ i.d., $5 \mu \mathrm{m}$; Varian, Netherlands) was used in series followed by the UV spectrophometric detector SPD-10A at $233 \mathrm{~nm}$ (Shimadzu, Kyoto, Japan). Isocratic mobile phase containing hexane/diethyl ether/acetonitril/2-propanol (99.35/0.5/ $0.1 / 0.05$, v:v:v:v) served as eluent at a flow rate of $1 \mathrm{~mL} /$ $\min$.

\section{Preparation of milk samples for in vitro experiments}

Investigation with natural complex lipids in vitro requires the presence of FFA (free fatty acids), since cells cannot absorb triacylglycerides (TAG) [22]. Against this background, preparation of FFA was conducted by means of an adapted procedure originally described by Bligh and Dyer [23]. Milk lipids (100 mg) were dissolved in $0.75 \mathrm{~mL}$ ethanol $(96 \%)$ and TAG were saponified with $0.75 \mathrm{~mL}$ of ethanolic sodium hydroxide $2 \mathrm{~N}$ at $70^{\circ}$ $\mathrm{C}$ for $30 \mathrm{~min}$. The solution was neutralized with $1.5 \mathrm{~mL}$ of hydrochloric acid $1 \mathrm{~N}$. FFA were extracted using 1.5 $\mathrm{mL}$ chloroform for $5 \mathrm{~min}$ under shaking. Two phases 
were achieved after adding $1.35 \mathrm{~mL}$ of $2 \%$ sodium chloride solution and $1.5 \mathrm{~mL}$ chloroform. After further shaking $(5 \mathrm{~min})$ and centrifugation $(2300 \times g)$, the lower phase was collected. Success of this process was confirmed by thin layer chromatography using hexane/ diethyl ether/formic acid (80/20/2, v:v:v). Distribution and amount of FFA were verified. After transesterfication to FAME with $2 \mathrm{~mL}$ of a methanolic boron trifluoride solution ( $5 \%$, wt:wt; $\left.100^{\circ} \mathrm{C}, 2 \mathrm{~min}\right)$, the distribution of FFA was analyzed by means of the two above-mentioned GC methods. Additionally, FA including C16:0, C18:0 and C18:1 $c 9$ were absolutely quantified by GCFID (60 m column) using the TAG tritricosanoin as internal standard (CPS Chemie, Aachen, Germany). Thereafter, total FFA levels were adjusted to $100 \mathrm{mM}$ in ethanol. Finally, the FA distribution and amounts of FFA-ML $\mathrm{Llp}_{\mathrm{al} / \mathrm{con}}$ in ethanol were measured by GC-FID as described above. Before usage in cell culture experiments, FFA-ML $\mathrm{alp}_{\mathrm{p} / \mathrm{con}}$ solutions were diluted with cell culture medium to $10 \mathrm{mM}$.

\section{Cell culture}

Human colon adenocarcinoma cells HT-29 were obtained from the American Tissue Culture Collection (ATCC) and maintained in Dulbecco's Modified Eagle's Medium (DMEM; $4.5 \mathrm{~g} / \mathrm{L}$ glucose, $58 \mathrm{mg} / \mathrm{L}$ L-glutamine, without sodium pyruvate; Invitrogen, Darmstadt, Germany) supplemented with fetal bovine serum (10\%, v:v; Biochrom, Berlin, Germany). Cells were cultivated as subconfluent monolayers in cell flasks $\left(\mathrm{T}-25 \mathrm{~cm}^{2}\right.$ and $\mathrm{T}$ $75 \mathrm{~cm}^{2}$; Greiner Bio one, Frickenhausen, Germany) under standard conditions at $37^{\circ} \mathrm{C}$ in a humidified culture incubator with 5\% carbon dioxide and 95\% humidity.

\section{Cell viability and growth parameters of HT-29 cells}

To obtain results of cell viability and growth parameters, 8000 cells/well were seeded onto a 96-well plate (Greiner Bio one, Frickenhausen, Germany) and were allowed to attach for $24 \mathrm{~h}$. Cells were then treated with two different types of complex milk lipids (FFA-ML $\mathrm{L}_{\mathrm{alp} / \mathrm{con}}$ ). Freshly prepared FFA solutions were added to a final volume of $200 \mu \mathrm{L}$ culture medium. Concentrations of $\mathrm{ML}_{\text {con }}$ and $\mathrm{ML}_{\mathrm{alp}}$ ranging from 5$250 \mu \mathrm{M}$ were chosen and incubated for $24 \mathrm{~h}, 48 \mathrm{~h}$ and $72 \mathrm{~h}$ and cell viability and growth parameters were determined by means of the CTB assay (CellTiter-Blue ${ }^{\circledR}$; Promega, Mannheim, Germany) and the DAPI assay (4',6-diamidino-2-phenylindole dihydrochloride; Carl Roth GmbH, Karlsruhe, Germany), respectively as previously described [24]. Results of cell viability and growth were calculated on the basis of percentage change to medium control containing $0.25 \%$ ethanol.
Fatty acid analysis after treatment with milk lipids Following incubation with $100 \mu \mathrm{M}$ and $200 \mu \mathrm{M}$ of $\mathrm{ML}_{\mathrm{alp} / \mathrm{con}}$ for $8 \mathrm{~h}$ and $24 \mathrm{~h}$ in $25 \mathrm{~cm}^{2}$ flasks, cells were washed with phosphate-buffered saline (PBS), detached from the flask by a trypsin/EDTA solution $(0.05 \% /$ $0.02 \%)$ and centrifuged at $700 \times g$ for $5 \mathrm{~min}$ at $8^{\circ} \mathrm{C}$. After discarding the supernatant the cell pellet was resolved in PBS. Protein content was determined by employing the Bradford method using bovine serum albumin as standard [25]. Cellular lipids were extracted with a methanol/chloroform mixture according to Bligh and Dyer [23]. Tritricosanoin was used as an internal standard. Derivatization of total lipids was conducted with $1 \mathrm{~mL}$ methanolic sodium hydroxide $0.5 \mathrm{~N}\left(100^{\circ} \mathrm{C}\right.$, $10 \mathrm{~min}$ ) followed by addition of $1 \mathrm{~mL}$ of a methanolic boron trifluoride solution (10\%, wt:wt; $\left.100^{\circ} \mathrm{C}, 2 \mathrm{~min}\right)$. FAME were extracted three times with hexane $(1 \times 2$ $\mathrm{mL}, 2 \times 1 \mathrm{~mL})$. Relative and absolute quantitative analyses of FAME extracts including CLA distribution by means of GC-FID and $\mathrm{Ag}^{+}$-HPLC were performed as described in the section milk samples and FA analysis.

\section{Statistical analysis}

All statistical analyses were performed using SPSS statistics, version $17.0\left({ }^{\circ} 2009\right.$ SPSS Inc, Illinois, USA). Results were presented as means \pm SD. Significant effects of $\mathrm{ML}_{\mathrm{alp} / \mathrm{con}}$ on cell viability and cell growth were assessed by one-way ANOVA followed by Dunnett's post hoc test (comparison to control group). The multiple comparisons were conducted with two-way ANOVA (milk type $\times$ FA-concentration) followed by Tukey's post hoc test to compare the results of FA analyses after different treatments. A value of $P<0.05$ was taken to indicate significance.

\section{Results}

\section{Characterisation of milk lipids}

The FA distribution of $\mathrm{ML}_{\text {con }}$ and $\mathrm{ML}_{\mathrm{alp}}$ showed significant differences depending on the types of milk lipids required to achieve ethanolic $\mathrm{FFA}-\mathrm{ML}_{\mathrm{con} / \mathrm{alp}}$ solutions (Table 1). FA distribution of $\mathrm{ML}_{\text {con }}$ showed high amounts of SFA (77.7\%) and MUFA (monounsaturated fatty acid) (19.9\%) and was characterized by low levels of PUFA (2.4\%) including $0.3 \%$ of total CLA. In contrast, FA distribution of $\mathrm{ML}_{\text {alp }}$ was characterized by decreased quantities of SFA (63.0\%), higher concentrations of MUFA (30.3\%), and PUFA (6.8\%) including 3.2\% of total CLA and, therefore, showed a significantly higher ratio of PUFA/SFA compared to $\mathrm{ML}_{\text {con }}$. However, concentrations of n-6 PUFA were similar to $M L_{c o n}$, whereas $n-3$ PUFA, C18:1 $t 11$ and CLA were significantly higher by factors of 3,10 and 9, respectively (Table 1A). Generally, the nutritional properties of the milk lipids were similar with regards to elevated levels of SFA. In contrast, since 
Table 1 Fatty acid distribution of milk lipids

\begin{tabular}{|c|c|c|c|c|c|c|c|c|c|c|c|c|c|c|c|c|}
\hline \multirow[b]{3}{*}{ FAME [\%] } & \multicolumn{8}{|c|}{ A } & \multicolumn{8}{|c|}{ B } \\
\hline & \multicolumn{4}{|c|}{$\mathrm{ML}_{\text {con }}$} & \multicolumn{4}{|c|}{$\mathrm{ML}_{\text {alp }}$} & \multicolumn{3}{|c|}{$\mathrm{ML}_{\text {con }}$} & \multicolumn{5}{|c|}{$\mathrm{ML}_{\mathrm{alp}}$} \\
\hline & Mean & & SD & & Mean & & SD & & Mean & & SD & & Mean & & SD & \\
\hline C14:0 & 12.32 & \pm & 0.51 & b & 9.67 & \pm & 0.25 & $d$ & 13.09 & \pm & 0.18 & $\mathrm{a}$ & 10.21 & \pm & 0.18 & $\mathrm{c}$ \\
\hline C14:1 C9 & 1.04 & \pm & 0.05 & b & 0.89 & \pm & 0.03 & d & 1.15 & \pm & 0.02 & a & 0.98 & \pm & 0.01 & c \\
\hline C15:0 & 1.24 & \pm & 0.05 & d & 1.35 & \pm & 0.02 & c & 1.47 & \pm & 0.04 & b & 1.58 & \pm & 0.04 & a \\
\hline C16:0 & 38.36 & \pm & 1.29 & b & 26.49 & \pm & 0.89 & d & 43.50 & \pm & 1.35 & a & 29.76 & \pm & 0.53 & c \\
\hline C16:1 c9 & 1.70 & \pm & 0.05 & b & 1.37 & \pm & 0.04 & d & 1.97 & \pm & 0.01 & a & 1.62 & \pm & 0.04 & c \\
\hline C17:0 & 0.56 & \pm & 0.02 & c & 0.68 & \pm & 0.01 & b & 0.68 & \pm & 0.02 & b & 0.79 & \pm & 0.01 & a \\
\hline C18:0 & 9.53 & \pm & 1.07 & & 10.19 & \pm & 0.85 & & 9.92 & \pm & 0.22 & & 10.54 & \pm & 0.26 & \\
\hline C18:1 c9 & 14.06 & \pm & 0.65 & d & 19.79 & \pm & 0.68 & b & 15.56 & \pm & 0.19 & c & 21.71 & \pm & 0.27 & a \\
\hline C18:1 C11 & 0.46 & \pm & 0.02 & d & 0.60 & \pm & 0.02 & b & 0.50 & \pm & 0.02 & c & 0.66 & \pm & 0.02 & a \\
\hline C18:1 C12-15 & 0.40 & \pm & 0.02 & b & 0.55 & \pm & 0.03 & a & 0.41 & \pm & 0.03 & b & 0.56 & \pm & 0.05 & a \\
\hline C18:1 t4-8 & 0.09 & \pm & 0.01 & b & 0.25 & \pm & 0.02 & a & 0.09 & \pm & 0.02 & b & 0.25 & \pm & 0.01 & b \\
\hline C18:1 t9 & 0.16 & \pm & 0.01 & b & 0.29 & \pm & 0.01 & a & 0.15 & \pm & 0.03 & b & 0.30 & \pm & 0.01 & a \\
\hline C18:1 t10 & 0.21 & \pm & 0.02 & c & 0.28 & \pm & 0.02 & b & 0.22 & \pm & 0.02 & c & 0.32 & \pm & 0.01 & a \\
\hline C18:1 t11 (VA) & 0.47 & \pm & 0.02 & c & 4.54 & \pm & 0.13 & b & 0.51 & \pm & 0.01 & c & 4.96 & \pm & 0.05 & a \\
\hline C18:1 t12-16 & 0.81 & \pm & 0.07 & c & 1.25 & \pm & 0.10 & b & 0.91 & \pm & 0.03 & c & 1.44 & \pm & 0.04 & a \\
\hline C18:2 n-6 & 1.06 & \pm & 0.09 & b & 1.30 & \pm & 0.06 & ab & 1.48 & \pm & 0.43 & ab & 1.73 & \pm & 0.38 & a \\
\hline C18:2 n-6 $(t, t)$ & 0.30 & \pm & 0.02 & c & 0.52 & \pm & 0.04 & b & 0.35 & \pm & 0.03 & c & 0.71 & \pm & 0.06 & a \\
\hline C18:2 c9,t11 & 0.31 & \pm & 0.03 & c & 2.77 & \pm & 0.13 & b & 0.32 & \pm & 0.04 & c & 3.04 & \pm & 0.08 & a \\
\hline $\mathrm{C} 18: 2 \mathrm{t} 11, \mathrm{c} 13$ & 0.00 & \pm & 0.00 & c & 0.25 & \pm & 0.01 & b & 0.00 & \pm & 0.00 & c & 0.29 & \pm & 0.02 & a \\
\hline$C 18: 2 t 9, t 11$ & 0.03 & \pm & 0.01 & c & 0.12 & \pm & 0.00 & b & 0.01 & \pm & 0.01 & d & 0.16 & \pm & 0.02 & a \\
\hline$C 18: 2 t 11, t 13$ & 0.00 & \pm & 0.00 & c & 0.05 & \pm & 0.00 & a & 0.00 & \pm & 0.00 & c & 0.04 & \pm & 0.01 & b \\
\hline C18:3 n-3 & 0.34 & \pm & 0.03 & d & 1.27 & \pm & 0.06 & b & 0.43 & \pm & 0.03 & c & 1.46 & \pm & 0.02 & a \\
\hline C20:0 & 0.21 & \pm & 0.11 & & 0.17 & \pm & 0.02 & & 0.20 & \pm & 0.04 & & 0.19 & \pm & 0.03 & \\
\hline C20:1 C9 & 0.02 & \pm & 0.00 & & 0.03 & \pm & 0.01 & & 0.04 & \pm & 0.02 & & 0.03 & \pm & 0.02 & \\
\hline$C 20: 3 n-6$ & 0.09 & \pm & 0.01 & & 0.07 & \pm & 0.01 & & 0.09 & \pm & 0.03 & & 0.07 & \pm & 0.02 & \\
\hline$C 20: 4$ n-6 & 0.10 & \pm & 0.01 & a & 0.07 & \pm & 0.00 & b & 0.10 & \pm & 0.01 & a & 0.08 & \pm & 0.02 & b \\
\hline$C 20: 5 n-3$ & 0.04 & \pm & 0.01 & b & 0.11 & \pm & 0.01 & a & 0.03 & \pm & 0.02 & b & 0.10 & \pm & 0.02 & a \\
\hline$C 22: 5 n-3$ & 0.09 & \pm & 0.01 & b & 0.12 & \pm & 0.00 & ab & 0.08 & \pm & 0.07 & b & 0.16 & \pm & 0.05 & a \\
\hline$\sum$ SCFA(C4 > C8) & 6.58 & \pm & 0.50 & a & 6.56 & \pm & 0.40 & a & 0.00 & \pm & 0.00 & b & 0.00 & \pm & 0.00 & b \\
\hline$\sum$ MCFA(C10 > C14) & 20.77 & \pm & 0.98 & a & 16.15 & \pm & 0.43 & c & 18.50 & \pm & 0.95 & b & 14.19 & \pm & 0.45 & d \\
\hline$\sum$ SFA & 77.73 & \pm & 1.00 & a & 62.95 & \pm & 1.17 & c & 75.25 & \pm & 0.74 & b & 58.98 & \pm & 0.35 & d \\
\hline$\sum$ MUFA & 19.89 & \pm & 0.81 & d & 30.29 & \pm & 0.93 & b & 21.67 & \pm & 0.21 & c & 33.02 & \pm & 0.33 & a \\
\hline$\sum$ PUFA incl. CLA & 2.38 & \pm & 0.19 & d & 6.76 & \pm & 0.25 & b & 3.07 & \pm & 0.58 & c & 8.01 & \pm & 0.38 & a \\
\hline$\sum$ PUFA n-3 & 0.48 & \pm & 0.05 & c & 1.58 & \pm & 0.06 & b & 0.56 & \pm & 0.11 & c & 1.83 & \pm & 0.05 & a \\
\hline$\sum$ PUFA n-6 & 1.26 & \pm & 0.10 & b & 1.46 & \pm & 0.06 & $\mathrm{ab}$ & 1.83 & \pm & 0.48 & a & 1.92 & \pm & 0.38 & a \\
\hline PUFA/SFA & 0.03 & \pm & 0.00 & d & 0.11 & \pm & 0.01 & b & 0.04 & \pm & 0.01 & c & 0.14 & \pm & 0.01 & a \\
\hline$n-6 / n-3$ & 2.60 & \pm & 0.12 & b & 0.93 & \pm & 0.01 & c & 3.26 & \pm & 0.23 & a & 1.05 & \pm & 0.19 & c \\
\hline$\Sigma S F A+t F A$ & 79.78 & \pm & 0.86 & $\mathrm{a}$ & 70.08 & \pm & 0.90 & c & 77.49 & \pm & 0.75 & b & 66.96 & \pm & 0.30 & d \\
\hline$\sum$ C18:1 (t) & 1.74 & \pm & 0.13 & c & 6.61 & \pm & 0.26 & b & 1.88 & \pm & 0.09 & c & 7.28 & \pm & 0.07 & a \\
\hline C18:1 t9/t11 & 0.35 & \pm & 0.01 & a & 0.06 & \pm & 0.00 & c & 0.30 & \pm & 0.05 & b & 0.06 & \pm & 0.00 & c \\
\hline$\Sigma C L A$ & 0.34 & \pm & 0.03 & c & 3.19 & \pm & 0.13 & b & 0.33 & \pm & 0.04 & c & 3.55 & \pm & 0.09 & a \\
\hline$V A+C 18: 2 c 9, t 11$ & 0.78 & \pm & 0.04 & c & 7.31 & \pm & 0.26 & b & 0.83 & \pm & 0.04 & c & 8.00 & \pm & 0.13 & a \\
\hline$\sum \mathrm{BCFA}$ & 1.75 & \pm & 0.05 & d & 2.39 & \pm & 0.08 & b & 2.11 & \pm & 0.06 & c & 2.80 & \pm & 0.03 & a \\
\hline
\end{tabular}

FA distribution of milk lipids from TAG (ML conventional and ML Alpine) before preparation (A) to FFA-mixtures suitable for cellular experiments, FA distribution of milk lipids as FFA-mixtures used for incubation of cells after saponification, extraction and solution (B) of milk lipids (FFA) in ethanol. Means ( $n=6)$ of FAME [\%] significantly differ without the same letter ${ }^{(a, b, c, d)}$, two-way ANOVA Tukey post hoc test $P<0.05$. 
$\mathrm{ML}_{\text {alp }}$ comprised a significantly higher unsaturated character, we considered this milk as being appropriate for the comparative study of complex milk lipids in vitro. The treatment of $\mathrm{ML}_{\text {con }}$ and $\mathrm{ML}_{\text {alp }}$ for the production of an ethanolic FFA solution (100 mM) led to a significant loss of SCFA (short-chain fatty acid) and a decrease in MCFA (middle-chain fatty acid) levels that resulted in a redistribution and percentage increase of the majority of FA (Table 1B). However, independent of the treatment procedure, a fraction of the FA, namely stearic acid (C18:0), arachidic acid (C20:0), gondoic acid (C20:1 $c 11)$, and dihomo- $\gamma$-linolenic acid (C20:3 n-6) remained generally unaffected.

The measurement with $\mathrm{Ag}^{+}$-HPLC ought to provide information relating to CLA isomer distribution and may help to elucidate the consequences of the treatment (Table 2). The distribution of CLA isomers differed significantly. As determined by GC analysis, $c 9, t 11$-CLA was the major isomer. The portion of this isomer with regards to CLA distribution was higher for $\mathrm{ML}_{\text {alp }}$ compared to $\mathrm{ML}_{\text {con }}$ (Tables 1 and 2). The second most abundant CLA isomers of $\mathrm{ML}_{\text {con }}$ and $\mathrm{ML}_{\text {alp }}$ were $t 7, c 9$ CLA (9\%) and $t 11, c 13$-CLA (8\%), respectively. The individual ratios of $t 11, c 13-\mathrm{CLA} / t 7, c 9$-CLA significantly differed by a factor of 17 and indicated an Alpine origin of the lipids as well as grazing on mountain pasture, as shown earlier [10]. Notably, the fraction of all-cis and all-trans-CLA of $\mathrm{ML}_{\text {con }}$ was significantly higher compared to $\mathrm{ML}_{\mathrm{alp}}$. Significant changes of the CLA profile during sample preparation of milk lipids to $\mathrm{FFA}-\mathrm{ML}_{\mathrm{con} /}$ alp were not observed (Table 2).

\section{Fatty acid analysis of HT-29 cells}

Incubation of HT-29 cells with complex lipids in the form of FFA derivatives prerequisites an analysis of the degree of FA incorporation allowing evaluation of the influence of different FA profiles on cellular lipid metabolism. FFA Concentrations of $100 \mu \mathrm{M}$ and $200 \mu \mathrm{M}$ were chosen because preliminary experiments showed no significant influence of these values on the viability of HT-29 cells. Results revealed that treatment with $\mathrm{ML}_{\text {con/alp }}$ led to a significant alteration of total cellular lipid content including FA distribution at $8 \mathrm{~h}$ and $24 \mathrm{~h}$ of incubation. Absolute quantitative determination showed a dose-dependent increase of the major FA C16:0 and C18:1 $c 9$ ( $\mu \mathrm{g} \mathrm{FA} / \mathrm{mg}$ cellular protein) at $8 \mathrm{~h}$ and $24 \mathrm{~h}$ of incubation (Figure 1). However, after $24 \mathrm{~h}$ of incubation the amount of total cellular lipids as measured for the two FA ( $\mu \mathrm{g} \mathrm{FA/mg} \mathrm{cellular} \mathrm{protein)}$ decreased in a time-dependent manner with the exception of C16:0 and C18:1 $c 9$ after incubation with 200 $\mu \mathrm{M}$ of $\mathrm{ML}_{\mathrm{con},}$. Cellular lipid content of control did not

Table 2 Fatty acid distribution of CLA isomers in different milk lipids

\begin{tabular}{|c|c|c|c|c|c|c|c|c|c|c|c|c|c|c|c|c|}
\hline \multirow[b]{3}{*}{ CLA FAME [\%] } & \multicolumn{8}{|c|}{ A } & \multicolumn{8}{|c|}{ B } \\
\hline & \multicolumn{3}{|c|}{$\mathrm{ML}_{\text {con }}$} & & \multicolumn{3}{|c|}{$\mathrm{ML}_{\mathrm{alp}}$} & & \multicolumn{3}{|c|}{$\mathrm{ML}_{\text {con }}$} & \multicolumn{5}{|c|}{$\mathrm{ML}_{\mathrm{alp}}$} \\
\hline & Mean & & SD & & Mean & & SD & & Mean & & SD & & Mean & & SD & \\
\hline$t 12, t 14$ & 2.36 & \pm & 0.08 & $\mathrm{a}$ & 0.96 & \pm & 0.01 & $\mathbf{b}$ & 2.34 & \pm & 0.16 & $\mathrm{a}$ & 1.00 & \pm & 0.02 & $\mathbf{b}$ \\
\hline$t 11, t 13$ & 4.19 & \pm & 0.09 & a & 1.86 & \pm & 0.05 & $\mathbf{b}$ & 4.05 & \pm & 0.16 & a & 1.92 & \pm & 0.06 & b \\
\hline$t 10, t 12$ & 0.95 & \pm & 0.07 & $\mathrm{a}$ & 0.17 & \pm & 0.04 & b & 0.97 & \pm & 0.09 & a & 0.33 & \pm & 0.09 & b \\
\hline$t 9, t 11$ & 2.68 & \pm & 0.24 & b & 0.54 & \pm & 0.03 & c & 3.27 & \pm & 0.16 & a & 0.85 & \pm & 0.20 & c \\
\hline$t 8, t 10$ & 1.41 & \pm & 0.08 & a & 0.19 & \pm & 0.03 & b & 1.53 & \pm & 0.21 & a & 0.22 & \pm & 0.09 & b \\
\hline$t 7, t 9$ & 0.42 & \pm & 0.03 & a & 0.07 & \pm & 0.03 & b & 0.41 & \pm & 0.10 & a & 0.06 & \pm & 0.03 & b \\
\hline$\sum$ trans,trans & 12.18 & \pm & 0.24 & a & 3.84 & \pm & 0.07 & b & 12.69 & \pm & 0.74 & a & 4.42 & \pm & 0.44 & b \\
\hline$t 11, c 13$ & 1.51 & \pm & 0.15 & b & 7.88 & \pm & 0.02 & a & 1.29 & \pm & 0.08 & b & 7.83 & \pm & 0.09 & $\mathrm{a}$ \\
\hline$c 11, t 13$ & 0.39 & \pm & 0.14 & & 0.17 & \pm & 0.03 & & 0.25 & \pm & 0.12 & & 0.24 & \pm & 0.07 & \\
\hline$t 10, c 12$ & 0.51 & \pm & 0.03 & $a b$ & 0.07 & \pm & 0.04 & b & 0.74 & \pm & 0.26 & a & 0.32 & \pm & 0.38 & $a b$ \\
\hline$c 9, t 11$ & 74.46 & \pm & 0.59 & b & 84.57 & \pm & 0.19 & $\mathrm{a}$ & 74.64 & \pm & 0.63 & b & 83.77 & \pm & 0.86 & $\mathrm{a}$ \\
\hline$t 8, c 10$ & 0.91 & \pm & 0.25 & & 0.60 & \pm & 0.13 & & 1.21 & \pm & 0.28 & & 0.61 & \pm & 0.27 & \\
\hline$t 7, c 9$ & 8.97 & \pm & 0.28 & a & 2.64 & \pm & 0.23 & b & 8.39 & \pm & 0.09 & a & 2.56 & \pm & 0.34 & b \\
\hline$\sum$ cis,trans/trans,cis & 86.90 & \pm & 0.25 & $\mathbf{b}$ & 95.99 & \pm & 0.02 & a & 86.62 & \pm & 0.75 & b & 95.39 & \pm & 0.42 & $\mathbf{a}$ \\
\hline$c 11, c 13$ & 0.07 & \pm & 0.04 & & 0.10 & \pm & 0.06 & & 0.10 & \pm & 0.06 & & 0.09 & \pm & 0.03 & \\
\hline$c 10, c 12$ & 0.10 & \pm & 0.08 & & - & & & & 0.05 & \pm & 0.01 & & - & & & \\
\hline$c 9, c 11$ & 0.67 & \pm & 0.20 & a & 0.07 & \pm & 0.01 & c & 0.54 & \pm & 0.30 & $a b$ & 0.10 & \pm & 0.01 & $a b$ \\
\hline$c 8, c 10$ & & - & & & & - & & & & - & & & & - & & \\
\hline$\sum \mathrm{cis} / \mathrm{cis}$ & 0.84 & \pm & 0.08 & $\mathrm{a}$ & 0.17 & \pm & 0.06 & b & 0.69 & \pm & 0.33 & a & 0.18 & \pm & 0.02 & b \\
\hline$t 11, c 13 / t 7, c 9$ & 0.17 & \pm & 0.02 & b & 3.00 & \pm & 0.26 & $\mathrm{a}$ & 0.15 & \pm & 0.01 & b & 3.10 & \pm & 0.48 & a \\
\hline
\end{tabular}

FA distribution of milk lipids from TAG (ML conventional and ML Alpine) before preparation (A) to FFA-mixtures suitable for cellular experiments, FA distribution of milk lipids as FFA-mixtures used for incubation of cells after saponification, extraction and solution (B) of milk lipids (FFA) in ethanol. Means ( $\mathrm{n}=6$ ) of FAME [\%] significantly differ without the same letter $(\mathrm{a}, \mathrm{b}, \mathrm{c}, \mathrm{d})$, two-way ANOVA Tukey post hoc test $P<0.05$. 

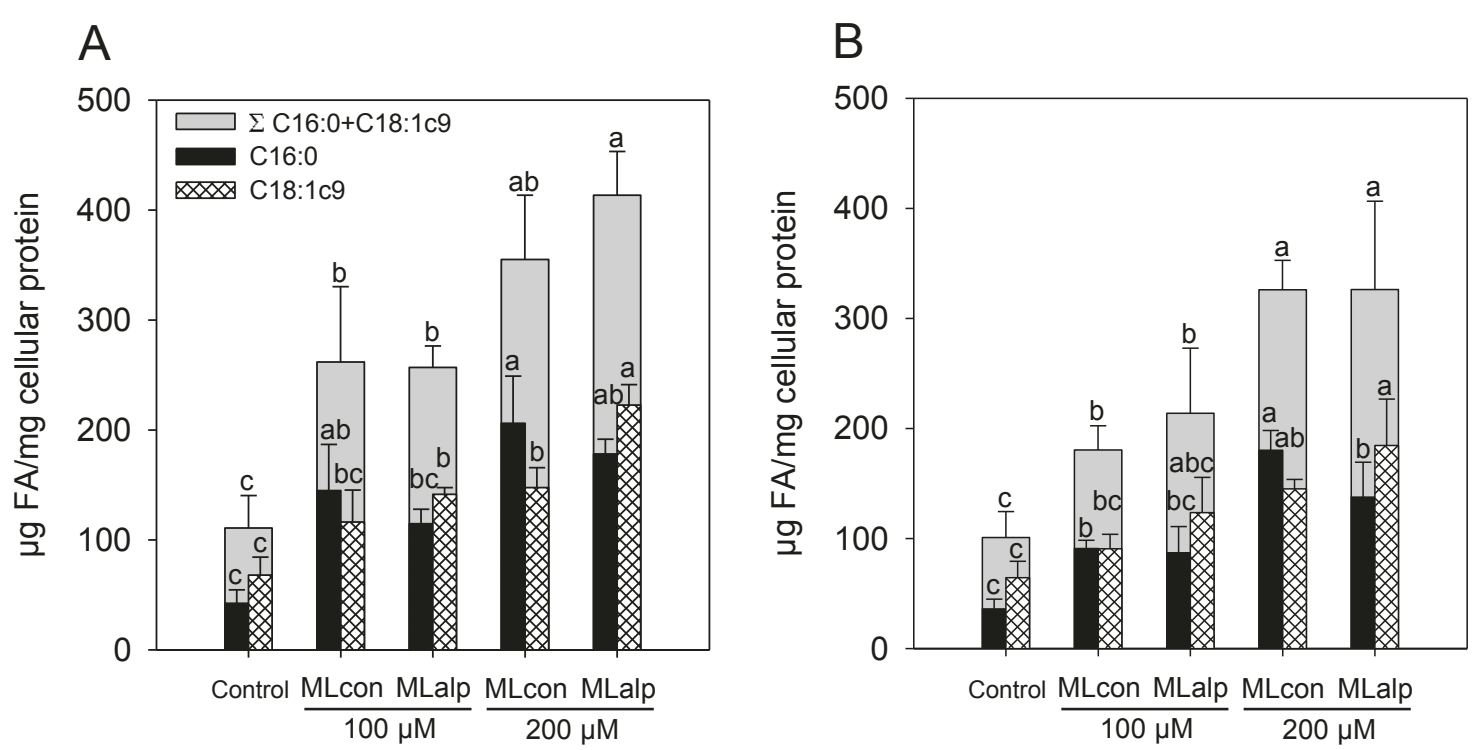

Figure 1 Quantitative amounts of fatty acids in cells after treatment with milk lipids. Total amount of two major FA of HT-29 cells after incubation with milk lipids (ML conventional and ML Alpine) given as FFA-mixtures in ethanol after $8 \mathrm{~h}(\mathbf{A})$ and $24 \mathrm{~h}(\mathbf{B})$ of incubation. Means ( $\mathrm{n}$ = 6) of $\mu \mathrm{g} \mathrm{FA/mg}$ cellular protein differ without the same letter ${ }^{(a, b, c)}$, two-way ANOVA Tukey post hoc test $P<0.05$.

change between $8 \mathrm{~h}$ and $24 \mathrm{~h}$. On subtracting the lipid content of untreated cells (control), the treatment with $\mathrm{ML}_{\mathrm{alp}}$ and $\mathrm{ML}_{\text {con }}$ led to a dose-dependent increase for both FA by 2 fold ( $\mathrm{ML}_{\mathrm{alp}} ; 8 \mathrm{~h}$ and $24 \mathrm{~h}$ of incubation), by 1.5 fold $\left(\mathrm{ML}_{\text {con }} ; 8 \mathrm{~h}\right)$ and by 3 fold $\left(\mathrm{ML}_{\text {con }} ; 24 \mathrm{~h}\right)$, respectively. Consequently, the main characteristics of the different milk lipids were reflected by these two important major FA. Thus, $\mathrm{ML}_{\text {con }}(200 \mu \mathrm{M}$ at $24 \mathrm{~h})$ led to the significantly highest concentration of one SFA (C16:0), whereas, in contrast, $\mathrm{ML}_{\text {alp }}$ caused the significantly highest concentration of one MUFA (C18:1 $c 9$ ) $(200 \mu \mathrm{M}$ at $8 \mathrm{~h})$. The sum of both FA reflected a dosedependent increase (Figure 1).

Relative quantitative analysis supported this observation and showed a significant alteration of cell lipid composition (Tables 3 and 4). The percentage of SFA was considerably increased after incubation with the milk lipids compared to the control. Typically, $\mathrm{ML}_{\text {con }}$ led to higher increase of SFA compared to $M L_{a l p}$. Otherwise, $\mathrm{ML}_{\text {alp }}$ led to higher portions of MUFA compared to $\mathrm{ML}_{\text {con }}$, but not to the control. Additionally, PUFA, including CLA were significantly lower after $8 \mathrm{~h}$ of incubation with $\mathrm{ML}_{\text {con }}$ compared to $\mathrm{ML}_{\text {alp }}$ and the control, and further decreased after $24 \mathrm{~h}$ with $\mathrm{ML}_{\mathrm{con}}$ and control compared to $\mathrm{ML}_{\mathrm{alp}}$. Notably, PUFA ( $\mathrm{n}-3$ and $n-6)$ were lower after incubation with milk lipids compared to the control. However, $\mathrm{ML}_{\text {con }}$ significantly increased whereas $\mathrm{ML}_{\mathrm{alp}}$ significantly decreased the ratio of $n-6 / n-3$ PUFA. In addition, $M_{\text {alp }}$ showed the highest dose-dependent portions of CLA, trans-C18:1 and BCFA in cellular lipids at $8 \mathrm{~h}$ and $24 \mathrm{~h}$ of incubation
(Tables 3 and 4). Particularly, a doubling of the concentration did not lead to further changes of FA composition for either incubation procedures. C18:1 $t 11$ converted to $c 9, t 11$-CLA dose- and time-dependently through $\Delta 9$-desaturation following incubation with $\mathrm{ML}_{\text {alp }}$. Generally, $\mathrm{ML}_{\text {alp }}$ significantly increased total CLA compared to $\mathrm{ML}_{\text {con }}$ by a factor of $8(100 \mu \mathrm{M})$ and 9 $(200 \mu \mathrm{M})$. The formation of conjugated metabolites was found only after incubation with $\mathrm{ML}_{\mathrm{alp}}$. Despite the low percentage of total CLA lipid content, C16:2 $c 7, t 9$ increased dose- and time-dependently (Tables 3 and 4).

The CLA composition of cellular lipids after incubation with the respective milk lipids was investigated using $\mathrm{Ag}^{+}$-HPLC (Table 5). Results showed the main characteristic portions of CLA after $8 \mathrm{~h}$ of incubation to be similar as compared to the distribution of CLA in intact milk lipids (Tables 2 and 5). Thus, $\mathrm{ML}_{\mathrm{con}}$-treated cells showed highest portions of all-trans-CLA and allcis-CLA as well as decreased levels of cis/trans, trans/ cis-CLA compared to the control and $\mathrm{ML}_{\mathrm{alp}}$. The ratio of $t 11, c 13$-CLA $/ t 7, c 9$-CLA significantly differed after treatment with milk lipids as mentioned above for the distribution of $\mathrm{ML}_{\text {con/alp }}$ (Tables 2 and 5).

\section{Effects of milk lipids on viability and growth}

The effects of lipids from two different milk sources $\left(\mathrm{ML}_{\text {alp }}, \mathrm{ML}_{\mathrm{con}}\right)$ on cell viability (CTB assay) and modulation of growth parameters (DAPI assay) were measured after incubation for $24 \mathrm{~h}, 48 \mathrm{~h}$ and $72 \mathrm{~h}$, respectively (Figure 2). Viability and growth of HT-29 cells were reduced in a dose- and time-dependent 
Table 3 Fatty acid distribution of cellular lipids treated with different milk lipids at $\mathbf{8} \mathbf{h}$

\begin{tabular}{|c|c|c|c|c|c|c|c|c|c|c|c|c|c|c|c|c|c|c|c|c|}
\hline \multirow[b]{3}{*}{ FAME [\%] } & \multirow{2}{*}{\multicolumn{4}{|c|}{$\begin{array}{c}\text { Control } \\
0.25 \% \text { EtOH }\end{array}$}} & \multicolumn{8}{|c|}{$\mathrm{ML}_{\text {con }}$} & \multicolumn{8}{|c|}{$M L_{\text {alp }}$} \\
\hline & & & & & \multicolumn{3}{|c|}{$100 \mu \mathrm{M}$} & \multicolumn{5}{|c|}{$200 \mu \mathrm{M}$} & \multicolumn{3}{|c|}{$100 \mu \mathrm{M}$} & \multicolumn{5}{|c|}{$200 \mu \mathrm{M}$} \\
\hline & Mean & & SD & & Mean & & SD & & Mean & & SD & & Mean & & SD & & Mean & & SD & \\
\hline C14:0 & 1.58 & \pm & 0.39 & d & 6.38 & \pm & 0.87 & $\mathrm{bc}$ & 7.96 & \pm & 0.94 & a & 5.38 & \pm & 0.57 & c & 6.81 & \pm & 0.51 & $\mathrm{ab}$ \\
\hline C14:1 C9 & 0.10 & \pm & 0.04 & d & 0.24 & \pm & 0.05 & $\mathrm{bc}$ & 0.33 & \pm & 0.05 & $a$ & 0.22 & \pm & 0.05 & c & 0.30 & \pm & 0.03 & $a b$ \\
\hline C15:0 & 0.25 & \pm & 0.03 & d & 1.02 & \pm & 0.09 & $\mathrm{bc}$ & 1.18 & \pm & 0.08 & a & 1.08 & \pm & 0.09 & c & 1.28 & \pm & 0.07 & $a b$ \\
\hline C16:0 & 20.92 & \pm & 0.95 & d & 34.53 & \pm & 1.89 & b & 36.96 & \pm & 1.35 & a & 26.52 & \pm & 1.14 & c & 26.77 & \pm & 0.99 & c \\
\hline C16:1 c9 & 12.75 & \pm & 0.74 & a & 8.11 & \pm & 0.80 & b & 6.64 & \pm & 0.52 & c & 7.11 & \pm & 0.51 & $\mathrm{bc}$ & 5.58 & \pm & 0.36 & d \\
\hline $\mathrm{C} 16: 2+7, \mathrm{C} 9$ & & - & & & & - & & & & - & & & 0.03 & \pm & 0.01 & b & 0.05 & \pm & 0.01 & a \\
\hline C17:0 & 0.44 & \pm & 0.03 & c & 0.64 & \pm & 0.04 & b & 0.63 & \pm & 0.02 & b & 0.69 & \pm & 0.04 & a & 0.67 & \pm & 0.02 & $a b$ \\
\hline C18:0 & 13.02 & \pm & 0.47 & a & 10.23 & \pm & 0.29 & b & 9.34 & \pm & 0.63 & c & 10.13 & \pm & 0.37 & b & 8.66 & \pm & 0.27 & c \\
\hline C18:1 C9 & 34.32 & \pm & 0.82 & a & 25.93 & \pm & 1.71 & c & 25.02 & \pm & 1.66 & c & 29.23 & \pm & 1.32 & b & 29.05 & \pm & 1.34 & b \\
\hline C18:1 C11 & 3.25 & \pm & 0.18 & a & 1.85 & \pm & 0.24 & b & 1.47 & \pm & 0.08 & c & 1.90 & \pm & 0.12 & b & 1.56 & \pm & 0.07 & c \\
\hline C18:1 C12-15 & & - & & & 0.31 & \pm & 0.10 & b & 0.39 & \pm & 0.09 & $a b$ & 0.42 & \pm & 0.13 & $a b$ & 0.48 & \pm & 0.11 & a \\
\hline C18:1 t4-8 & & - & & & 0.03 & \pm & 0.01 & $\mathrm{bc}$ & 0.03 & \pm & 0.01 & bc & 0.08 & \pm & 0.06 & $a b$ & 0.11 & \pm & 0.05 & a \\
\hline C18:1 t9 & & - & & & 0.10 & \pm & 0.03 & b & 0.10 & \pm & 0.04 & b & 0.16 & \pm & 0.04 & $\mathrm{ab}$ & 0.19 & \pm & 0.07 & a \\
\hline C18:1 t10 & & - & & & 0.14 & \pm & 0.04 & b & 0.18 & \pm & 0.03 & b & 0.19 & \pm & 0.04 & b & 0.25 & \pm & 0.05 & a \\
\hline C18:1 t11 (VA) & & - & & & 0.27 & \pm & 0.03 & c & 0.34 & \pm & 0.03 & c & 2.50 & \pm & 0.20 & $\mathrm{~b}$ & 3.32 & \pm & 0.16 & a \\
\hline C18:1 t12-16 & & - & & & 0.42 & \pm & 0.14 & c & 0.54 & \pm & 0.18 & $b c$ & 0.75 & \pm & 0.19 & $a b$ & 0.92 & \pm & 0.20 & a \\
\hline C18:2 n-6 & 2.65 & \pm & 0.13 & a & 2.08 & \pm & 0.05 & $\mathrm{~cd}$ & 2.04 & \pm & 0.17 & d & 2.28 & \pm & 0.07 & b & 2.25 & \pm & 0.11 & $b c$ \\
\hline C18:2 n-6 $(t, t)$ & & - & & & 0.21 & \pm & 0.06 & d & 0.29 & \pm & 0.03 & c & 0.43 & \pm & 0.04 & b & 0.54 & \pm & 0.03 & a \\
\hline C18:2 c9,t11 & 0.09 & \pm & 0.01 & e & 0.32 & \pm & 0.01 & d & 0.37 & \pm & 0.03 & c & 2.47 & \pm & 0.07 & b & 3.18 & \pm & 0.14 & a \\
\hline C18:2 t11,c13 & & - & & & & - & & & & - & & & 0.18 & \pm & 0.02 & b & 0.26 & \pm & 0.02 & a \\
\hline C18:2 t9,t11 & & - & & & 0.03 & \pm & 0.01 & $c d$ & 0.04 & \pm & 0.01 & c & 0.18 & \pm & 0.02 & b & 0.24 & \pm & 0.03 & a \\
\hline C18:3 n-3 & 0.22 & \pm & 0.03 & d & 0.33 & \pm & 0.02 & c & 0.42 & \pm & 0.05 & c & 0.96 & \pm & 0.02 & b & 1.31 & \pm & 0.09 & a \\
\hline C20:0 & 0.38 & \pm & 0.03 & a & 0.30 & \pm & 0.02 & b & 0.24 & \pm & 0.03 & c & 0.28 & \pm & 0.02 & b & 0.20 & \pm & 0.02 & c \\
\hline C20:1 C9 & 0.33 & \pm & 0.07 & a & 0.17 & \pm & 0.04 & $\mathrm{bc}$ & 0.15 & \pm & 0.02 & d & 0.23 & \pm & 0.04 & b & 0.18 & \pm & 0.02 & $b c$ \\
\hline C20:3 n-6 & 1.19 & \pm & 0.14 & a & 0.63 & \pm & 0.05 & b & 0.49 & \pm & 0.04 & $c d$ & 0.58 & \pm & 0.06 & $b c$ & 0.42 & \pm & 0.05 & d \\
\hline C20:4 n-6 & 2.38 & \pm & 0.25 & a & 1.20 & \pm & 0.09 & b & 0.86 & \pm & 0.05 & c & 1.13 & \pm & 0.13 & $\mathrm{~b}$ & 0.77 & \pm & 0.09 & c \\
\hline C20:5 n-3 & 0.70 & \pm & 0.05 & a & 0.35 & \pm & 0.04 & $\mathrm{bc}$ & 0.27 & \pm & 0.02 & d & 0.39 & \pm & 0.03 & b & 0.31 & \pm & 0.03 & $c d$ \\
\hline C22:5 n-3 & 1.34 & \pm & 0.15 & a & 0.70 & \pm & 0.11 & b & 0.53 & \pm & 0.06 & c & 0.69 & \pm & 0.08 & $\mathrm{bc}$ & 0.54 & \pm & 0.07 & $b c$ \\
\hline C22:6 n-3 & 1.76 & \pm & 0.16 & a & 0.82 & \pm & 0.11 & b & 0.58 & \pm & 0.05 & c & 0.78 & \pm & 0.10 & $\mathrm{~b}$ & 0.53 & \pm & 0.07 & c \\
\hline$\Sigma$ SFA & 38.65 & \pm & 0.88 & a & 55.47 & \pm & 2.59 & b & 58.67 & \pm & 1.83 & a & 46.78 & \pm & 1.59 & c & 47.29 & \pm & 1.66 & c \\
\hline$\sum$ MUFA & 50.84 & \pm & 0.34 & b & 37.69 & \pm & 2.28 & c & 35.30 & \pm & 1.49 & c & 42.91 & \pm & 1.34 & b & 42.07 & \pm & 1.22 & b \\
\hline$\sum$ PUFA incl. CLA & 10.51 & \pm & 0.86 & a & 6.84 & \pm & 0.47 & b & 6.03 & \pm & 0.44 & b & 10.31 & \pm & 0.44 & a & 10.64 & \pm & 0.56 & a \\
\hline$\sum$ PUFA n-3 & 4.14 & \pm & 0.36 & a & 2.31 & \pm & 0.28 & c & 1.88 & \pm & 0.16 & c & 2.95 & \pm & 0.21 & $\mathrm{~b}$ & 2.82 & \pm & 0.22 & b \\
\hline$\sum$ PUFA n-6 & 6.28 & \pm & 0.51 & a & 3.98 & \pm & 0.18 & $\mathrm{bc}$ & 3.46 & \pm & 0.25 & d & 4.07 & \pm & 0.25 & b & 3.54 & \pm & 0.23 & $c d$ \\
\hline PUFA/SFA & 0.27 & \pm & 0.03 & a & 0.12 & \pm & 0.01 & c & 0.10 & \pm & 0.01 & c & 0.22 & \pm & 0.02 & b & 0.23 & \pm & 0.02 & b \\
\hline$n-6 / n-3$ & 1.52 & \pm & 0.06 & b & 1.74 & \pm & 0.17 & a & 1.85 & \pm & 0.07 & a & 1.38 & \pm & 0.03 & $\mathrm{bc}$ & 1.26 & \pm & 0.02 & c \\
\hline$\Sigma S F A+t F A$ & 38.65 & \pm & 0.88 & d & 56.71 & \pm & 2.73 & b & 60.23 & \pm & 2.06 & a & 50.97 & \pm & 2.04 & c & 52.73 & \pm & 1.91 & c \\
\hline$\sum C 18: 1(t)$ & & - & & & 0.96 & \pm & 0.18 & c & 1.18 & \pm & 0.26 & c & 3.68 & \pm & 0.46 & b & 4.79 & \pm & 0.38 & a \\
\hline C18:1 t9,t11 & & - & & & 0.37 & \pm & 0.10 & a & 0.28 & \pm & 0.09 & a & 0.06 & \pm & 0.01 & b & 0.06 & \pm & 0.02 & b \\
\hline$\Sigma C L A$ & 0.09 & \pm & 0.01 & d & 0.35 & \pm & 0.02 & c & 0.41 & \pm & 0.04 & c & 2.83 & \pm & 0.07 & $\mathrm{~b}$ & 3.68 & \pm & 0.15 & a \\
\hline$V A+C 18: 2 c 9, t 11$ & 0.09 & \pm & 0.01 & d & 0.59 & \pm & 0.04 & c & 0.71 & \pm & 0.03 & c & 4.97 & \pm & 0.25 & b & 6.50 & \pm & 0.30 & a \\
\hline$\sum B C F A$ & 0.44 & \pm & 0.12 & d & 1.59 & \pm & 0.15 & c & 1.83 & \pm & 0.13 & b & 1.97 & \pm & 0.16 & $\mathrm{~b}$ & 2.38 & \pm & 0.14 & a \\
\hline
\end{tabular}

FA distribution of HT-29 cells after incubation with milk lipids (ML conventional and ML Alpine) given as FFA-mixtures in ethanol. Means ( $\mathrm{n}=6$ ) of FAME [\%] significantly differ without the same letter $(\mathrm{a}, \mathrm{b}, \mathrm{c}, \mathrm{d})$, two-way ANOVA Tukey post hoc test $P<0.05$.

manner. In particular, concentrations of $5 \mu \mathrm{M}-50 \mu \mathrm{M}$ showed no effects compared to control. $\mathrm{ML}_{\text {con }}$ and $\mathrm{ML}_{\text {alp }}$ significantly reduced cell growth after treatment with $150 \mu \mathrm{M}(24 \mathrm{~h})$ to $75 \%$ and $72 \%$, respectively.
Viability was significantly decreased after $250 \mu \mathrm{M}$ at 24 $\mathrm{h}$ of incubation. After $48 \mathrm{~h}$, both lipids caused a decrease of cell viability and growth at $150 \mu \mathrm{M}$. After 48 $\mathrm{h}$ and $72 \mathrm{~h}$ of incubation, this was also observed for 
Table 4 Fatty acid distribution of cellular lipids treated with different milk lipids at $\mathbf{2 4} \mathbf{h}$

\begin{tabular}{|c|c|c|c|c|c|c|c|c|c|c|c|c|c|c|c|c|c|c|c|c|}
\hline \multirow[b]{3}{*}{ FAME [\%] } & \multirow{2}{*}{\multicolumn{4}{|c|}{$\begin{array}{c}\text { Control } \\
0.25 \% \mathrm{EtOH}\end{array}$}} & \multicolumn{8}{|c|}{$\mathrm{ML}_{\text {con }}$} & \multicolumn{8}{|c|}{$\mathrm{ML}_{\text {alp }}$} \\
\hline & & & & & \multicolumn{3}{|c|}{$100 \mu \mathrm{M}$} & \multicolumn{5}{|c|}{$200 \mu \mathrm{M}$} & \multicolumn{3}{|c|}{$100 \mu \mathrm{M}$} & \multicolumn{5}{|c|}{$200 \mu \mathrm{M}$} \\
\hline & Mean & & SD & & Mean & & SD & & Mean & & SD & & Mean & & SD & & Mean & & SD & \\
\hline C14:0 & 1.67 & \pm & 0.32 & d & 6.26 & \pm & 0.34 & b & 8.33 & \pm & 0.61 & $a$ & 5.36 & \pm & 0.28 & c & 6.86 & \pm & 0.46 & b \\
\hline C14:1 C9 & 0.17 & \pm & 0.06 & c & 0.55 & \pm & 0.09 & $a b$ & 0.67 & \pm & 0.15 & a & 0.46 & \pm & 0.06 & b & 0.54 & \pm & 0.07 & $a b$ \\
\hline C15:0 & 0.21 & \pm & 0.01 & c & 0.81 & \pm & 0.06 & b & 1.04 & \pm & 0.04 & a & 0.85 & \pm & 0.04 & b & 1.12 & \pm & 0.05 & a \\
\hline C16:0 & 20.48 & \pm & 0.71 & d & 30.34 & \pm & 1.27 & b & 34.36 & \pm & 1.34 & a & 24.56 & \pm & 0.65 & c & 25.57 & \pm & 0.29 & c \\
\hline C16:1 C9 & 15.44 & \pm & 0.97 & a & 11.82 & \pm & 1.23 & b & 9.45 & \pm & 1.09 & c & 9.31 & \pm & 0.95 & c & 6.96 & \pm & 0.73 & d \\
\hline$C 16: 2+7, C 9$ & & - & & & & - & & & & - & & & 0.07 & \pm & 0.01 & b & 0.08 & \pm & 0.00 & $\mathrm{a}$ \\
\hline C17:0 & 0.32 & \pm & 0.01 & a & 0.54 & \pm & 0.04 & c & 0.59 & \pm & 0.03 & b & 0.59 & \pm & 0.04 & b & 0.68 & \pm & 0.03 & d \\
\hline C18:0 & 10.97 & \pm & 0.89 & a & 9.39 & \pm & 0.32 & b & 8.77 & \pm & 0.34 & b & 9.03 & \pm & 0.21 & b & 8.71 & \pm & 0.25 & b \\
\hline C18:1 C9 & 36.95 & \pm & 0.87 & a & 28.67 & \pm & 0.64 & d & 26.09 & \pm & 0.27 & e & 31.63 & \pm & 0.99 & b & 30.27 & \pm & 0.34 & c \\
\hline C18:1 C11 & 3.04 & \pm & 0.20 & a & 1.77 & \pm & 0.15 & b & 1.33 & \pm & 0.09 & a & 1.84 & \pm & 0.05 & b & 1.39 & \pm & 0.11 & a \\
\hline C18:1 C12-15 & & - & & & 0.29 & \pm & 0.15 & a & 0.38 & \pm & 0.07 & a & 0.41 & \pm & 0.13 & a & 0.43 & \pm & 0.10 & a \\
\hline C18:1 t4-8 & & - & & & 0.02 & \pm & 0.01 & bc & 0.04 & \pm & 0.02 & bc & 0.07 & \pm & 0.04 & $a b$ & 0.10 & \pm & 0.05 & a \\
\hline C18:1 t9 & & - & & & 0.09 & \pm & 0.02 & c & 0.12 & \pm & 0.03 & bc & 0.15 & \pm & 0.04 & ab & 0.20 & \pm & 0.06 & a \\
\hline C18:1 t10 & & - & & & 0.10 & \pm & 0.02 & b & 0.14 & \pm & 0.03 & b & 0.14 & \pm & 0.04 & b & 0.20 & \pm & 0.03 & a \\
\hline C18:1 t11 (VA) & & - & & & 0.18 & \pm & 0.04 & c & 0.28 & \pm & 0.05 & c & 1.86 & \pm & 0.25 & b & 2.73 & \pm & 0.27 & a \\
\hline C18:1 t12-16 & & - & & & 0.35 & \pm & 0.09 & c & 0.58 & \pm & 0.08 & b & 0.56 & \pm & 0.13 & b & 0.81 & \pm & 0.18 & a \\
\hline C18:2 n-6 & 2.13 & \pm & 0.18 & a & 1.91 & \pm & 0.12 & bc & 1.73 & \pm & 0.07 & c & 2.13 & \pm & 0.09 & a & 2.00 & \pm & 0.04 & ab \\
\hline C18:2 n-6 $(t, t)$ & & - & & & 0.13 & \pm & 0.05 & d & 0.22 & \pm & 0.03 & c & 0.28 & \pm & 0.05 & b & 0.42 & \pm & 0.03 & a \\
\hline C18:2 c9,t11 & 0.07 & \pm & 0.02 & d & 0.35 & \pm & 0.02 & c & 0.40 & \pm & 0.02 & c & 2.90 & \pm & 0.27 & b & 3.57 & \pm & 0.18 & a \\
\hline $\mathrm{C} 18: 2 \mathrm{t} 11, \mathrm{c} 13$ & & - & & & & - & & & & - & & & 0.15 & \pm & 0.02 & b & 0.21 & \pm & 0.02 & a \\
\hline$C 18: 2 t 9, t 11$ & & - & & & 0.04 & \pm & 0.01 & c & 0.04 & \pm & 0.01 & c & 0.19 & \pm & 0.02 & b & 0.21 & \pm & 0.02 & a \\
\hline C18:3 n-3 & 0.20 & \pm & 0.03 & d & 0.35 & \pm & 0.03 & c & 0.39 & \pm & 0.03 & c & 1.03 & \pm & 0.09 & b & 1.26 & \pm & 0.06 & a \\
\hline C20:0 & 0.35 & \pm & 0.02 & a & 0.30 & \pm & 0.02 & b & 0.28 & \pm & 0.01 & bc & 0.30 & \pm & 0.01 & b & 0.27 & \pm & 0.01 & c \\
\hline C20:1 C9 & 0.41 & \pm & 0.05 & a & 0.19 & \pm & 0.04 & cd & 0.15 & \pm & 0.00 & d & 0.26 & \pm & 0.02 & b & 0.21 & \pm & 0.01 & bc \\
\hline C20:3 n-6 & 0.97 & \pm & 0.12 & a & 0.55 & \pm & 0.01 & b & 0.38 & \pm & 0.01 & c & 0.53 & \pm & 0.02 & b & 0.36 & \pm & 0.02 & c \\
\hline C20:4 n-6 & 1.82 & \pm & 0.19 & a & 1.00 & \pm & 0.02 & b & 0.66 & \pm & 0.03 & c & 0.95 & \pm & 0.04 & b & 0.63 & \pm & 0.04 & c \\
\hline C20:5 n-3 & 0.53 & \pm & 0.05 & a & 0.29 & \pm & 0.02 & bc & 0.21 & \pm & 0.01 & d & 0.33 & \pm & 0.02 & b & 0.25 & \pm & 0.01 & cd \\
\hline C22:5 n-3 & 1.04 & \pm & 0.15 & a & 0.59 & \pm & 0.03 & b & 0.42 & \pm & 0.01 & c & 0.62 & \pm & 0.05 & b & 0.43 & \pm & 0.03 & c \\
\hline$C 22: 6 n-3$ & 1.31 & \pm & 0.12 & a & 0.70 & \pm & 0.03 & b & 0.45 & \pm & 0.03 & c & 0.70 & \pm & 0.05 & b & 0.43 & \pm & 0.04 & c \\
\hline$\Sigma$ SFA & 35.66 & \pm & 1.27 & e & 49.81 & \pm & 1.52 & b & 55.66 & \pm & 1.15 & a & 43.14 & \pm & 1.00 & d & 45.98 & \pm & 0.53 & c \\
\hline$\sum$ MUFA & 56.10 & \pm & 1.15 & a & 44.15 & \pm & 1.60 & c & 39.35 & \pm & 1.17 & d & 46.84 & \pm & 0.86 & b & 43.99 & \pm & 0.63 & c \\
\hline$\sum$ PUFA incl. CLA & 8.24 & \pm & 0.78 & b & 6.04 & \pm & 0.20 & c & 4.99 & \pm & 0.06 & d & 10.05 & \pm & 0.57 & a & 10.03 & \pm & 0.17 & a \\
\hline$\sum$ PUFA n-3 & 3.20 & \pm & 0.34 & a & 2.01 & \pm & 0.07 & d & 1.51 & \pm & 0.04 & e & 2.78 & \pm & 0.17 & b & 2.47 & \pm & 0.04 & c \\
\hline$\sum$ PUFA n-6 & 4.97 & \pm & 0.47 & a & 3.51 & \pm & 0.13 & b & 2.82 & \pm & 0.06 & c & 3.67 & \pm & 0.13 & b & 3.07 & \pm & 0.04 & c \\
\hline PUFA/SFA & 0.23 & \pm & 0.03 & a & 0.12 & \pm & 0.00 & b & 0.09 & \pm & 0.00 & c & 0.23 & \pm & 0.02 & a & 0.22 & \pm & 0.00 & a \\
\hline$n-6 / n-3$ & 1.56 & \pm & 0.07 & c & 1.75 & \pm & 0.07 & b & 1.87 & \pm & 0.07 & a & 1.32 & \pm & 0.03 & d & 1.25 & \pm & 0.01 & d \\
\hline$\Sigma S F A+t F A$ & 35.66 & \pm & 1.27 & d & 50.75 & \pm & 1.62 & b & 57.13 & \pm & 1.33 & a & 46.28 & \pm & 1.17 & c & 50.56 & \pm & 1.04 & b \\
\hline$\sum C 18: 1(t)$ & & - & & & 0.74 & \pm & 0.16 & c & 1.16 & \pm & 0.18 & c & 2.78 & \pm & 0.45 & b & 4.05 & \pm & 0.55 & a \\
\hline C18:1 t9/t11 & & - & & & 0.51 & \pm & 0.07 & a & 0.42 & \pm & 0.07 & b & 0.08 & \pm & 0.02 & c & 0.07 & \pm & 0.02 & c \\
\hline$\Sigma C L A$ & 0.07 & \pm & 0.02 & d & 0.39 & \pm & 0.02 & c & 0.44 & \pm & 0.02 & c & 3.26 & \pm & 0.33 & b & 3.99 & \pm & 0.17 & a \\
\hline$V A+C 18: 2 C 9, t 11$ & 0.07 & \pm & 0.02 & d & 0.52 & \pm & 0.05 & $\mathrm{~cd}$ & 0.68 & \pm & 0.06 & c & 4.75 & \pm & 0.52 & b & 6.30 & \pm & 0.40 & a \\
\hline$\sum$ BCFA & 0.37 & \pm & 0.10 & d & 1.36 & \pm & 0.13 & c & 1.68 & \pm & 0.10 & b & 1.72 & \pm & 0.17 & b & 2.16 & \pm & 0.11 & a \\
\hline
\end{tabular}

FA distribution of HT-29 cells after incubation with milk lipids (ML conventional and ML Alpine) given as FFA-mixtures in ethanol. Means $(n=6)$ of FAME [\%] significantly differ without the same letter $(\mathrm{a}, \mathrm{b}, \mathrm{c}, \mathrm{d})$, two-way ANOVA Tukey post hoc test $P<0.05$.

$\mathrm{ML}_{\text {con }}$ at $100 \mu \mathrm{M}$ (Figure 2). There were no significant differences between the milk lipids regarding the influence on viability and growth of HT-29 cells at any time point (Figure 2).

\section{Discussion}

Naturally and synthetically derived CLA has been shown to act against artherogenesis, hypertension, diabetes, inflammation and cancer $[26,27]$. Whereas numerous 
Table 5 CLA isomers in cellular lipids of HT-29 treated with different milk lipids at 8 h

\begin{tabular}{|c|c|c|c|c|c|c|c|c|c|c|c|c|c|c|c|c|c|c|c|c|}
\hline \multirow[b]{3}{*}{ CLA FAME [\%] } & \multirow{2}{*}{\multicolumn{4}{|c|}{$\begin{array}{c}\text { Control } \\
0.25 \% \mathrm{EtOH}\end{array}$}} & \multicolumn{8}{|c|}{$\mathrm{ML}_{\text {con }}$} & \multicolumn{8}{|c|}{$\mathrm{ML}_{\mathrm{alp}}$} \\
\hline & & & & & \multicolumn{3}{|c|}{$100 \mu \mathrm{M}$} & \multicolumn{5}{|c|}{$200 \mu \mathrm{M}$} & \multicolumn{3}{|c|}{$100 \mu \mathrm{M}$} & \multicolumn{5}{|c|}{$200 \mu \mathrm{M}$} \\
\hline & Mean & & SD & & Mean & & SD & & Mean & & SD & & Mean & & SD & & Mean & & SD & \\
\hline$t 12, t 14$ & & - & & & & - & & & & - & & & & - & & & & - & & \\
\hline$t 11, t 13$ & & - & & & 2.63 & \pm & 0.71 & $\mathrm{a}$ & 2.76 & \pm & 0.26 & a & 1.26 & \pm & 0.14 & b & 1.31 & \pm & 0.06 & b \\
\hline$t 10, t 12$ & & - & & & 0.69 & \pm & 0.23 & a & 0.82 & \pm & 0.09 & a & 0.24 & \pm & 0.09 & b & 0.26 & \pm & 0.09 & b \\
\hline$t 9, t 11$ & 3.15 & \pm & 1.28 & a & 3.08 & \pm & 0.49 & a & 3.35 & \pm & 0.51 & a & 1.18 & \pm & 0.35 & b & 1.14 & \pm & 0.34 & b \\
\hline$t 8, t 10$ & & - & & & 0.28 & \pm & 0.15 & ab & 0.47 & \pm & 0.16 & a & 0.02 & \pm & 0.01 & bc & 0.11 & \pm & 0.02 & bc \\
\hline$t 7, t 9$ & 2.86 & \pm & 0.79 & a & 0.89 & \pm & 0.28 & b & 0.73 & \pm & 0.08 & b & 0.09 & \pm & 0.05 & b & 0.05 & \pm & 0.01 & b \\
\hline$\sum$ trans, trans & 6.02 & \pm & 2.06 & bc & 8.38 & \pm & 1.19 & $a b$ & 9.68 & \pm & 0.30 & a & 3.48 & \pm & 0.53 & c & 3.57 & \pm & 0.50 & c \\
\hline$t 11, c 13$ & 4.88 & \pm & 3.15 & $a b$ & 3.59 & \pm & 1.20 & ab & 1.81 & \pm & 0.30 & b & 6.54 & \pm & 0.47 & a & 6.83 & \pm & 0.34 & a \\
\hline$c 11, t 13$ & 3.00 & \pm & 1.89 & $\mathrm{a}$ & 1.80 & \pm & 0.93 & ab & 1.17 & \pm & 0.25 & ab & 0.31 & \pm & 0.06 & b & 0.36 & \pm & 0.10 & b \\
\hline$t 10, c 12$ & 3.82 & \pm & 1.39 & a & 3.48 & \pm & 1.11 & b & 1.61 & \pm & 0.75 & $a b$ & 0.42 & \pm & 0.27 & b & 0.22 & \pm & 0.15 & b \\
\hline$c 9, t 11$ & 77.28 & \pm & 3.25 & b & 74.65 & \pm & 0.80 & a & 76.12 & \pm & 0.98 & b & 86.66 & \pm & 1.17 & a & 87.14 & \pm & 0.80 & a \\
\hline$t 8, c 10$ & 0.63 & \pm & 0.45 & $a b$ & 0.78 & \pm & 0.58 & ab & 1.20 & \pm & 0.25 & a & 0.44 & \pm & 0.10 & ab & 0.18 & \pm & 0.10 & b \\
\hline$t 7, c 9$ & 4.38 & \pm & 1.55 & bc & 6.09 & \pm & 1.58 & $\mathrm{~cd}$ & 7.18 & \pm & 0.55 & a & 1.82 & \pm & 0.20 & cd & 1.44 & \pm & 0.11 & d \\
\hline$\sum$ cis,trans/trans,cis & 93.98 & \pm & 2.06 & a & 90.39 & \pm & 1.23 & b & 89.09 & \pm & 0.38 & b & 96.19 & \pm & 0.61 & a & 96.17 & \pm & 0.59 & a \\
\hline$c 11, c 13$ & & - & & & & - & & & & - & & & 0.08 & \pm & 0.02 & & 0.03 & \pm & 0.00 & \\
\hline$c 10, c 12$ & & - & & & & - & & & & - & & & & - & & & & - & & \\
\hline$c 9, c 11$ & & - & & & 1.23 & \pm & 0.10 & a & 1.18 & \pm & 0.09 & a & 0.26 & \pm & 0.08 & b & 0.23 & \pm & 0.09 & b \\
\hline$c 8, c 10$ & & - & & & & - & & & & - & & & & - & & & & - & & \\
\hline$\sum \mathrm{cis} / \mathrm{cis}$ & & - & & & 1.23 & \pm & 0.10 & $\mathrm{a}$ & 1.18 & \pm & 0.09 & a & 0.34 & \pm & 0.09 & b & 0.26 & \pm & 0.09 & b \\
\hline$t 11, c 13 / t 7, c 9$ & 1.33 & \pm & 1.25 & b & 0.64 & \pm & 0.34 & b & 0.25 & \pm & 0.06 & b & 3.63 & \pm & 0.46 & a & 4.77 & \pm & 0.55 & a \\
\hline
\end{tabular}

CLA distribution of HT-29 cells after incubation with milk lipids (ML conventional and ML Alpine) given as FFA-mixtures in ethanol. Means ( $\mathrm{n}=6$ ) of FAME [\%] significantly differ without the same letter ${ }^{(a, b, c, d)}$, two-way ANOVA Tukey post hoc test $P<0.05$.

studies indicate anticarcinogenic effects mostly due to single isomers, such as $c 9, t 11$-CLA or $t 10, c 12$-CLA $[9,28]$ in different model systems, little is known about both the mode of action of isolated CLA isomers and their effectiveness when applied as a natural composition. Therefore, it is important to mimic the absorption of functional lipid ingredients in human gut with milk and dairy products. To test the potentially synergetic effects of FFA mixtures in vitro, HT-29 cells were treated with Alpine milk lipids richer in CLA, the precursor of CLA (C18:1 t11), and n-3 PUFA than conventional milk lipids.

First, we established an in vitro method that enabled us to test FFA mixtures of milk lipids. Alterations in milk lipid characteristics were monitored by this method. The SCFA fraction was excluded because levels of butyrate and other SCFA were not significantly different between the two types of milk, i.e., $\mathrm{ML}_{\mathrm{alp}}, \mathrm{ML}_{\text {con }}$ (Table 1). Furthermore, treatment with a mixture of PUFA and butyrate enhanced apoptosis of HT-29 cells [29]. Since the human gut is the main SCFA source of butyrate [30], we investigated potentially anticarcinogenic properties of milk fat in vitro considering only FA of chain lengths of over C8:0. Short saponification times $(30 \mathrm{~min})$ at a higher temperature $\left(70^{\circ} \mathrm{C}\right)$ instead of the previously reported saponification conditions were more successful [31]. FFA were separated from total lipids and the prevention of oxidative artifacts, especially of the CLA isomers was proven by means of $\mathrm{Ag}^{+}$-HPLC analysis (Table 2). Although larger fractions of FA were enriched as a result of this method, the composition of the milk lipids was preserved and no effect on the distribution of important FA such as CLA isomers was detectable (Tables 1 and 2). Differences in the origin and type of feed were reflected by the respective milk lipid composition (Table 1). The results confirmed the typical FA distribution of $\mathrm{ML}_{\mathrm{alp}}$ and represented grazing food conditions in the Alps as described earlier [10,32]. Moreover, our results attested fatty acid distribution of $\mathrm{ML}_{\text {con }}$ to intensive feeding conditions [11].

In addition to the fact that effects of a mixture of lipids of ruminant origin have been poorly studied in vitro, incorporation of milk lipid FA into cellular lipids has also been scantily investigated to date. However, the treatment of HT-29 cells involving $8 \mathrm{~h}$ and $24 \mathrm{~h}$ of incubation described herein verified not only the uptake and utilization of the FA mixtures, but also indicated a relationship of FA distribution and growth inhibition in HT-29 cells. Cell lipid content and FA composition were affected differently depending on treatment with $\mathrm{ML}_{\text {con }}$ or $\mathrm{ML}_{\mathrm{alp}}$. Whereas both milk lipids led to a comparable increase of total lipids, the ratio of the 

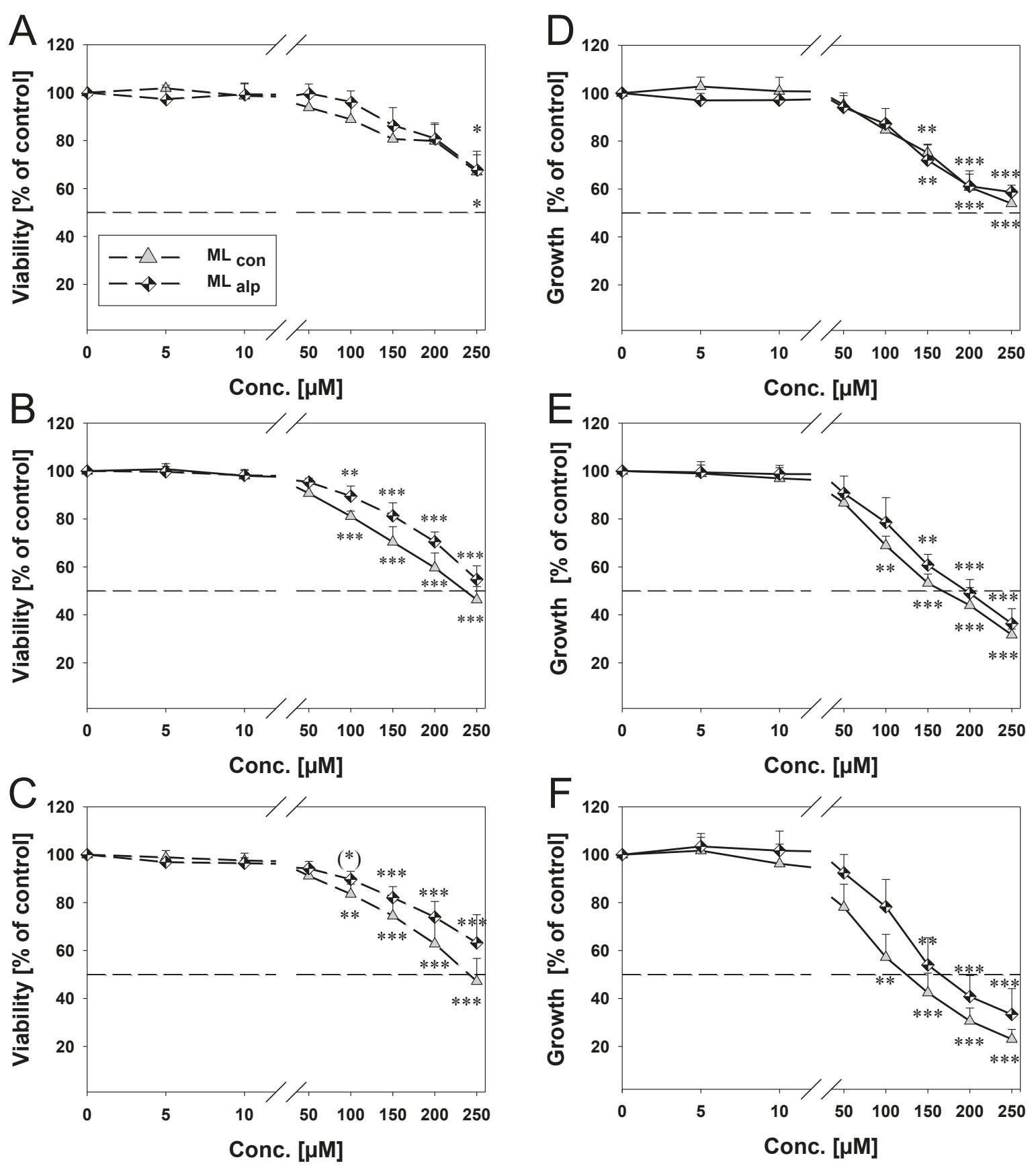

Figure 2 Effects of milk lipids on viability and growth of HT-29 cells. Cell viability was measured by means of the CTB assay (left; A 24 h, B $48 \mathrm{~h}, \mathbf{C} 72 \mathrm{~h}$ ) and growth parameter of the cells was measured by means of DAPI assay (right; D $24 \mathrm{~h}, \mathbf{E} 48 \mathrm{~h}, \mathbf{F} 72 \mathrm{~h}$ ). Means $(\mathrm{n}=6)$ are significantly different from control, one-way ANOVA Dunnett post hoc test $\left.{ }^{*}\right) P<0.1,{ }^{*} P<0.05$, ** $P<0.001$, *** $P<0.0001$.

determined major FA (C16:0/C18:1 $c 9 \mu \mathrm{g} \mathrm{FA/mg} \mathrm{pro-}$ tein) differed between $\mathrm{ML}_{\text {con }}$ and $\mathrm{ML}_{\text {alp }}$ (Figure 1). By simply determining C16:0 and C18:1 $c 9$ by means of GC-FID, the different origins of applied milk lipids and type of feeding could be distinguished. Acquisition of total major FA with total cellular protein yielded a decrease of FA after $24 \mathrm{~h}$. Thus, a complete incorporation of milk lipids even after $8 \mathrm{~h}$ can be assumed (Figure 1).

Relative quantitative analysis of total cellular lipids following incubation with milk confirmed the high SFA proportion of total cellular lipids (Tables 3 and 4). Both milk lipids, $\mathrm{ML}_{\text {con }}$ more than $\mathrm{ML}_{\text {alp }}$, led to an inversion of the SFA/MUFA ratio compared to control at $8 \mathrm{~h}$. 
Notably, incubation with $\mathrm{ML}_{\text {alp }}$ showed prolonged percentage of PUFA compared to $\mathrm{ML}_{\mathrm{con}}$ and control within cellular lipid distribution at $24 \mathrm{~h}$. Generally, a doubling of the milk lipid concentration did not lead to a doubling of potentially favorable FA such as CLA and n-3 PUFA as shown by absolute quantitative analysis of C16:0 and C18:1 $c 9$. This observation emphasizes the contrast to other investigations in which single purified isomers were used and showed a 2 fold increase of the administrated single FA in cellular lipids corresponding to the doubling of the FA concentration [33,34]. However, the absolute quantitative analysis in the present study showed a dose-dependent doubling of the major FA such as C16:0 and C18:1 $c 9$. This important outcome strongly suggests that total CLA and other rumen-specific FA (C18:1 $t 11$, BCFA) might be also doubled in a dose-dependent manner. Moreover, the results herein confirm that incubation of HT-29 cells with different milk lipids led to the incorporation of CLA into cellular lipids which remained consistent, although the majority of PUFA decreased time-dependently. A similar observation was made with C18:3 n-3 (Tables 3 and 4). Finally, the conversion of C18:1 $t 11$ to $c 9, t 11$-CLA also contributed to an enhancement of total CLA in cellular lipids. Nevertheless, it remains questionable whether the daily consumption of Alpine milk and Alpine dairy products can raise the percentage of CLA into cellular lipids in vivo compared to in vitro. However, elevated amounts of total CLA and the CLA precursor C18:1 t11 in the tested $\mathrm{ML}_{\text {alp }}$ can positively contribute to improve cellular levels of CLA in vivo. Thus, future human studies should further investigate if an equal intake of $\mathrm{ML}_{\text {alp }}$ compared to $\mathrm{ML}_{\text {con }}$ leads to 8 fold higher values of total CLA in cellular lipids as shown by the results of this study (Tables 3 and 4).

Anticancer activity of CLA was shown to be associated with modulation of cellular signal transduction $[28,35,36]$. Hence, it cannot be excluded that 8-9 fold lower amounts of CLA in $\mathrm{ML}_{\text {con }}$ similarly influence cellular signaling pathways after incubation. Accordingly, these results can plausibly explain why a low concentration of between $0.1 \%$ and $1 \%$ CLA in the rodent diet was sufficient to produce anticarcinogenic effects $[37,38]$.

The remarkable difference in the ratio of $t 11, c 13$ CLA/ $t 7, c 9$-CLA was determined by means of Ag ${ }^{+}$-HPLC. This ratio can be used as a prospective marker for application of milk lipids with Alpine origin in a cellular model (Table 5). However, the influence of different CLA profiles and minor isomers such as $t 11, c 13$ CLA of Alpine milk on cellular lipid metabolism remains unclear.

Information on the interaction of conjugated fatty acids on FA metabolism is derived from the analysis of directly formed metabolites of CLA isomers (e.g. conjugated dienes; CD16:2, CD20:2, CD22:2) [39]. Analysis of these metabolites is important as it cannot be excluded that they also exhibit specific biological activity. For example, $c 9, t 11$-CLA can be metabolized to C16:2 $c 7, t 9$ by $\beta$-oxidation [39]. We found the metabolite $C 16: 2 c 7$, t9 immediately following treatment with $\mathrm{ML}_{\text {alp }}$ (Tables 3 and 4 ) at a percentage of below $0.1 \%$. Moreover, the dose- and time-dependent $\beta$-oxidation of the major $c 9$, t11-CLA isomer by HT-29 cells was evident (Tables 3 and 4). Although, it cannot be excluded that other metabolites could also be formed after incubation with $\mathrm{ML}_{\mathrm{alp}}$, it is likely that concentrations of these metabolites would be extremely low.

Distribution of other cellular lipids was, moreover, affected by incubation with milk lipids. The dose- and time- dependent decrease of other PUFA such as C20:4 n6 (arachidonic acid) was shown in this study (Tables 3 and 4). This decrease must be interpreted as a dilution effect because milk lipids are naturally poor in LCPUFA (> C20, long-chain). Stimulation experiments with milk lipids significantly decreased the percentage of n-6 as well as n-3 LC-PUFA (Tables 3 and 4) though absolute quantitative reduction remains questionable. Nevertheless, treatment with milk lipids [16] or CLA isomers [40] can partially inhibit conversion of LCPUFA such as C20:4 n6 to eicosanoids, which are important FA derivatives that negatively affect tumorigenesis [41].

Viability and growth of the cells was reduced in a dose- and time-dependent manner on treatment with the two different milk lipids. However, there was no significant difference between the treatment with $\mathrm{ML}_{\text {con }}$ and $\mathrm{ML}_{\mathrm{alp}}$ on these two parameters. Hence, it can be concluded that naturally occurring higher amounts of beneficial anticarcinogenic compounds like CLA, CLA precursor (C18:1 t11), and n-3 PUFA in Alpine milk fat did not increase anticarcinogenic activity of milk lipids in HT-29 cells at all. Generally, synergistic effects cannot be excluded when cells are treated with a mixture of lipids. Our results confirm data from an in vitro study of De La Torre et al. (2006) showing that a complete mixture of FA with low CLA content $(<1 \%)$ obtained from beef extract led to stronger growth inhibition of cancer cell lines compared to the fraction comprising of CLA-mixtures only. Indeed, FA from beef extract $(100 \mu \mathrm{M})$ reduced cell numbers of different cell lines by $30-70 \%$ at $48 \mathrm{~h}$ of incubation [17] which was comparable to our study data. However, treatment of HT-29 cells with $\mathrm{ML}_{\text {alp }}$ demonstrated an 8-9 fold increase of CLA that was not stronger compared to $\mathrm{ML}_{\text {con }}$. Notably, low concentrations $(5 \mu \mathrm{M}$ and $10 \mu \mathrm{M})$ showed no beneficial effects on proliferation of the cell line since $C 16: 0$ and $C 18: 1 c 9$ are able to enhance 
cancer cell growth $[42,43]$. Physiological concentrations of total FFA in vivo are reported to range between 400 $800 \mu \mathrm{M}$ [44]. No data are available from the literature regarding the association between consumption of milk lipids and the resulting plasma concentration. In general, it is entirely conceivable that concentrations below $100 \mu \mathrm{M}$ used herein could result from dietary intake of ruminant lipids. However, higher concentrations up to $250 \mu \mathrm{M}$ emphasized the dose-effect relationship of the descriptive data from the in vitro experiments (Figure 2).

Other milk fat ingredients can also be responsible for the growth inhibitory effects found in this study. In particular, a health-beneficial potential was shown for BCFA (e.g. phytanic acid) in dairy lipids [49]. Treatment of colon cancer cells with ubiquitin and vitamin D, both constituents of milk fat, also led to inhibition of cell growth $[50,51]$. The repeated and continuous dietary intake of CLA in vivo showed elevated inhibitory effects on tumorigenesis [38]. It is, therefore, possible that the multiday incubation of $\mathrm{ML}_{\text {alp }}$ at lower concentrations affect the growth of HT-29 cells differently compared to $\mathrm{ML}_{\text {con }}$. Further reasons for cell growth inhibition are likely to emerge, since CLA isomers are capable of inducing apoptosis and affecting cell cycle and DNA synthesis [36,52,53]. All-trans-CLA seem to exert increased growth inhibitory effects compared to CLA isomers with cis configuration [40,52-54]. Therefore, in further studies it will be of interest to determine whether FA mixtures rich in all-trans-CLA support this observation.

Several studies showed a dependency on anticarcinogenic effects in vitro [33] and in vivo [45-47] due to conversion of C18:1 $t 11$ to CLA. This conversion of C18:1 $t 11$ occurred immediately after treatment with $\mathrm{ML}_{\text {alp }}$ in this study, but did not additionally contribute to growth inhibition compared to cells incubated with $\mathrm{ML}_{\text {con }}$, which were low in C18:1 $t 11$ (Table 3). Furthermore, incubation with $\mathrm{ML}_{\text {con }}$ markedly led to a significantly decreased PUFA/ SFA ratio compared to control and $\mathrm{ML}_{\text {alp }}$ treated cells (Table 4). The altered ratio was shown to be associated with increased apoptosis and inhibition of proliferation of PC-3 prostate cancer cells [48].

\section{Conclusions}

This study showed significant changes of cell FA distribution and total amounts of cellular lipids after treatment with milk lipids of conventional or Alpine origin. Both milk lipid mixtures, in the form of FFA-solutions, effectively decreased viability and growth of HT-29 cells. However, concerning the inhibitory potential, no differences of these milk lipid mixtures were observed. Since the FA profile of the milk lipids determines the profile of the cell lipids, it might be promising to extend this feature to other cell lines. The intake of milk and dairy products is beneficial to health from the nutritional point of view, particularly with regards to colorectal cancer. However, mechanistic studies in vitro are required to distinguish between potential anticarcinogenic effects of single major isomers ( $c 9, t 11$-CLA), single minor isomers $(t 11, c 13-\mathrm{CLA})$, and complex lipids and to verify the efficacy in combination with other fatty acids and their corresponding matrix.

\section{Abbreviations}

BCFA: branched-chain fatty acid; CLA: conjugated linoleic acid; FA: fatty acid; FAME: fatty acid methylesters; FFA: free fatty acids; HT-29: human colon adenocarcinoma cells; LC-PUFA: long-chain PUFA; MCFA: middle-chain fatty acid; MLalp: Alpine milk lipids; $\mathrm{ML}_{\text {con: }}$ conventional milk lipids; MUFA: monounsaturated fatty acid; PBS: phosphate-buffered saline; PUFA: polyunsaturated fatty acid; SCFA: short-chain fatty acid; SFA: saturated fatty acid; TAG: triacylglycerides; VA: vaccenic acid

\section{Acknowledgements}

This work was supported by grants from Deutsche Forschungsgemeinschaft (JA 893/5-3 and JA 893/9-1)

Dr. U. Schaefer (Friedrich-Schiller-University Jena, Institute of Nutrition, Dept. of Nutritional Physiology) is acknowledged for encouragement and the proofreading of the manuscript and thanks to $\mathrm{N}$. Kroegel for language editing.

\section{Author details}

'Friedrich-Schiller-University, Institute of Nutrition, Dept. of Nutritional Physiology, Dornburger Str. 24, Jena, Germany. 2Institute of Animal Nutrition, Friedrich Loeffler Institute (FLI), Federal Research Institute for Animal Health, Braunschweig, Germany.

\section{Authors' contributions}

$C D$ conceived and carried out the study design, participated in the preparation of milk lipids, cell culture experiments, FA analysis by GC-FID, and performed $\mathrm{Ag}^{+}-\mathrm{HPLC}$ analysis, as well as conducting the determination of cell viability and growth, plus determining the cellular protein, analyzing the data, performing the statistical analysis and drafting the manuscript. AL participated in the study design and was involved in the preparation of milk lipids, cell culture experiments and absolute and relative quantitative FA analysis. SK participated in absolute quantitative FA analysis. KK participated in relative quantitative FA analysis with $\mathrm{Ag}^{+}-\mathrm{HPLC}$. SD coordinated and performed a study with cows to provide conventional milk lipid samples. GJ helped to conceive the study, participated in its design and coordination and helped to draft the manuscript. All authors read and approved the final manuscript.

\section{Competing interests}

The authors declare that they have no competing interests.

Received: 24 June 2011 Accepted: 4 August 2011

Published: 4 August 2011

\section{References}

1. Randi G, Edefonti V, Ferraroni M, La Vecchia C, Decarli A: Dietary patterns and the risk of colorectal cancer and adenomas. Nutr Rev 2010, 68(7):389-408.

2. Escrich E, Moral R, Grau L, Costa I, Solanas M: Molecular mechanisms of the effects of olive oil and other dietary lipids on cancer. Mol Nutr Food Res 2007, 51(10):1279-1292.

3. Parodi PW: Conjugated linoleic acid and other anticarcinogenic agents of bovine milk fat. J Dairy Sci 1999, 82(6):1339-1349.

4. Pufulete M: Intake of dairy products and risk of colorectal neoplasia. Nutr Res Rev 2008, 21(1):56-67.

5. Kuriki K, Wakai K, Hirose K, Matsuo K, Ito H, Suzuki T, Saito T, Kanemitsu Y, Hirai $T$, Kato T, et al: Risk of colorectal cancer is linked to erythrocyte compositions of fatty acids as biomarkers for dietary intakes of fish, fat, and fatty acids. Cancer Epidemiol Biomarkers Prev 2006, 15(10):1791-1798. 
6. Parodi PW: Dairy product consumption and the risk of breast cancer. $J$ Am Coll Nutr 2005, 24(6 Suppl):556S-568S.

7. Thiebaut AC, Jiao L, Silverman DT, Cross AJ, Thompson FE, Subar AF, Hollenbeck AR, Schatzkin A, Stolzenberg-Solomon RZ: Dietary fatty acids and pancreatic cancer in the NIH-AARP diet and health study. J Natl Cancer Inst 2009, 101(14):1001-1011.

8. Larsson SC, Bergkvist L, Wolk A: Conjugated linoleic acid intake and breast cancer risk in a prospective cohort of Swedish women. Am J Clin Nutr 2009, 90(3):556-560.

9. Kelley NS, Hubbard NE, Erickson KL: Conjugated linoleic acid isomers and cancer. J Nutr 2007, 137(12):2599-2607.

10. Kraft J, Collomb M, Mockel P, Sieber R, Jahreis G: Differences in CLA isomer distribution of cow's milk lipids. Lipids 2003, 38(6):657-664.

11. Shingfield KJ, Bernard L, Leroux C, Chilliard Y: Role of trans fatty acids in the nutritional regulation of mammary lipogenesis in ruminants. Animal 2010, 4(7):1140-1166

12. Ip C, Banni S, Angioni E, Carta G, McGinley J, Thompson HJ, Barbano D, Bauman D: Conjugated linoleic acid-enriched butter fat alters mammary gland morphogenesis and reduces cancer risk in rats. J Nutr 1999, 129(12):2135-2142.

13. Hubbard NE, Lim D, Erickson KL: Beef tallow increases the potency of conjugated linoleic acid in the reduction of mouse mammary tumor metastasis. J Nutr 2006, 136(1):88-93.

14. Shiraishi R, Iwakiri R, Fujise T, Kuroki T, Kakimoto T, Takashima T, Sakata Y, Tsunada S, Nakashima Y, Yanagita T, et al: Conjugated linoleic acid suppresses colon carcinogenesis in azoxymethane-pretreated rats with long-term feeding of diet containing beef tallow. J Gastroenterol 2010, 45(6):625-635.

15. O'Shea M, Devery R, Lawless F, Murphy J, Stanton C: Milk fat conjugated linoleic acid (CLA) inhibits growth of human mammary MCF-7 cancer cells. Anticancer Res 2000, 20(5B):3591-3601.

16. Miller A, Stanton C, Murphy J, Devery R: Conjugated linoleic acid (CLA)enriched milk fat inhibits growth and modulates CLA-responsive biomarkers in MCF-7 and SW480 human cancer cell lines. Br J Nutr 2003, 90(5):877-885

17. De La Torre A, Debiton E, Juaneda P, Durand D, Chardigny JM, Barthomeuf C, Bauchart D, Gruffat D: Beef conjugated linoleic acid isomers reduce human cancer cell growth even when associated with other beef fatty acids. Br J Nutr 2006, 95(2):346-352.

18. Serini S, Piccioni E, Merendino N, Calviello G: Dietary polyunsaturated fatty acids as inducers of apoptosis: implications for cancer. Apoptosis 2009, 14(2):135-152.

19. Keese C, Meyer U, Rehage J, Spilke J, Boguhn J, Breves G, Danicke S: On the effects of the concentrate proportion of dairy cow rations in the presence and absence of a fusarium toxin-contaminated triticale on cow performance. Arch Anim Nutr 2008, 62(3):241-262.

20. Jaudszus A, Moeckel P, Hamelmann E, Jahreis G: Trans-10,cis-12-CLAcaused lipodystrophy is associated with profound changes of fatty acid profiles of liver, white adipose tissue and erythrocytes in mice: possible link to tissue-specific alterations of fatty acid desaturation. Ann Nutr Metab 2010, 57(2):103-111.

21. Kuhnt $K$, Degen C, Jahreis $G$ : 2-Propanol in the mobile phase reduces the time of analysis of CLA isomers by silver ion-HPLC. J Chromatogr B Analyt Technol Biomed Life Sci 2010, 878(1):88-91.

22. Iqbal J, Hussain MM: Intestinal lipid absorption. Am J Physiol Endocrinol Metab 2009, 296(6):E1183-1194

23. Bligh EG, Dyer WJ: A rapid method of total lipid extraction and purification. Can J Biochem Physiol 1959, 37(8):911-917.

24. Klenow S, Pool-Zobel BL, Glei M: Influence of inorganic and organic iron compounds on parameters of cell growth and survival in human colon cells. Toxicol In Vitro 2009, 23(3):400-407.

25. Bradford MM: A rapid and sensitive method for the quantitation of microgram quantities of protein utilizing the principle of protein-dye binding. Anal Biochem 1976, 72:248-254.

26. Bhattacharya A, Banu J, Rahman M, Causey J, Fernandes G: Biological effects of conjugated linoleic acids in health and disease. J Nutr Biochem 2006, 17(12):789-810.

27. Wahle KW, Heys SD, Rotondo D: Conjugated linoleic acids: are they beneficial or detrimental to health? Prog Lipid Res 2004, 43(6):553-587.

28. Lee KW, Lee HJ, Cho HY, Kim YJ: Role of the conjugated linoleic acid in the prevention of cancer. Crit Rev Food Sci Nutr 2005, 45(2):135-144.
29. Hofmanova J, Vaculova A, Lojek A, Kozubik A: Interaction of polyunsaturated fatty acids and sodium butyrate during apoptosis in HT-29 human colon adenocarcinoma cells. Eur J Nutr 2005, 44(1):40-51.

30. Hamer HM, Jonkers D, Venema K, Vanhoutvin S, Troost FJ, Brummer RJ: Review article: the role of butyrate on colonic function. Aliment Pharmacol Ther 2008, 27(2):104-119.

31. Bauchart D, Aurousseau B: Postprandial lipids in blood plasma of preruminant calves. J Dairy Sci 1981, 64(10):2033-2042.

32. Collomb M, Sieber R, Butikofer U: CLA isomers in milk fat from cows fed diets with high levels of unsaturated fatty acids. Lipids 2004, 39(4):355-364.

33. Miller A, McGrath E, Stanton C, Devery R: Vaccenic acid (t11-18:1) is converted to C9,t11-CLA in MCF-7 and SW480 cancer cells. Lipids 2003, 38(6):623-632

34. Ecker J, Liebisch G, Scherer M, Schmitz G: Differential effects of conjugated linoleic acid isomers on macrophage glycerophospholipid metabolism. J Lipid Res 2010, 51(9):2686-2694.

35. Bocca C, Bozzo F, Gabriel L, Miglietta A: Conjugated linoleic acid inhibits Caco-2 cell growth via ERK-MAPK signaling pathway. J Nutr Biochem 2007, 18(5):332-340.

36. Bozzo F, Bocca C, Colombatto S, Miglietta A: Antiproliferative effect of conjugated linoleic acid in caco-2 cells: involvement of PPARgamma and APC/beta-catenin pathways. Chem Biol Interact 2007, 169(2):110-121.

37. Ip C, Singh M, Thompson HJ, Scimeca JA: Conjugated linoleic acid suppresses mammary carcinogenesis and proliferative activity of the mammary gland in the rat. Cancer Res 1994, 54(5):1212-1215.

38. Ip C, Scimeca JA, Thompson H: Effect of timing and duration of dietary conjugated linoleic acid on mammary cancer prevention. Nutr Cancer 1995, 24(3):241-247.

39. Muller A, Ringseis R, Dusterloh K, Gahler S, Eder K, Steinhart H: Detection of conjugated dienoic fatty acids in human vascular smooth muscle cells treated with conjugated linoleic acid. Biochim Biophys Acta 2005, 1737(23):145-151.

40. Islam MA, Kim YS, Jang WJ, Lee SM, Kim HG, Kim SY, Kim JO, Ha YL: A mixture of trans, trans conjugated linoleic acid induces apoptosis in MCF-7 human breast cancer cells with reciprocal expression of Bax and Bcl-2. J Agric Food Chem 2008, 56(14):5970-5976.

41. Wu WK, Sung JJ, Lee CW, Yu J, Cho CH: Cyclooxygenase-2 in tumorigenesis of gastrointestinal cancers: an update on the molecular mechanisms. Cancer Lett 2010, 295(1):7-16.

42. Falconer JS, Ross JA, Fearon KC, Hawkins RA, O'Riordain MG, Carter DC: Effect of eicosapentaenoic acid and other fatty acids on the growth in vitro of human pancreatic cancer cell lines. Br J Cancer 1994, 69(5):826-832

43. Nano JL, Nobili C, Girard-Pipau F, Rampal P: Effects of fatty acids on the growth of Caco-2 cells. Prostaglandins Leukot Essent Fatty Acids 2003, 69(4):207-215

44. Hodson L, Skeaff CM, Fielding BA: Fatty acid composition of adipose tissue and blood in humans and its use as a biomarker of dietary intake. Prog Lipid Res 2008, 47(5):348-380.

45. Banni S, Angioni E, Murru E, Carta G, Melis MP, Bauman D, Dong Y, Ip C: Vaccenic acid feeding increases tissue levels of conjugated linoleic acid and suppresses development of premalignant lesions in rat mammary gland. Nutr Cancer 2001, 41(1-2):91-97.

46. Corl BA, Barbano DM, Bauman DE, Ip C: cis-9, trans-11 CLA derived endogenously from trans-11 18:1 reduces cancer risk in rats. J Nutr 2003, 133(9):2893-2900.

47. Lock AL, Corl BA, Barbano DM, Bauman DE, Ip C: The anticarcinogenic effect of trans-11 18:1 is dependent on its conversion to cis-9, trans-11 CLA by delta9-desaturase in rats. I Nutr 2004, 134(10):2698-2704.

48. Petrangeli E, Lenti L, Buchetti B, Chinzari P, Sale P, Salvatori L, Ravenna L, Lococo E, Morgante E, Russo A, et al: Lipido-sterolic extract of Serenoa repens (LSESr, Permixon) treatment affects human prostate cancer cell membrane organization. J Cell Physiol 2009, 219(1):69-76.

49. Hellgren LI: Phytanic acid-an overlooked bioactive fatty acid in dairy fat? Ann N Y Acad Sci 2010, 1190:42-49.

50. Freiburghaus C, Welinder C, Tjornstad U, Lindmark-Mansson H, Paulsson M, Oredsson S: Identification of ubiquitin in bovine milk and its growth inhibitory effects on human cancer cell lines. J Dairy Sci 2010, 93(8):3442-3452. 
51. Beildeck ME, Islam M, Shah S, Welsh J, Byers SW: Control of TCF-4 expression by VDR and vitamin $D$ in the mouse mammary gland and colorectal cancer cell lines. PLoS One 2009, 4(11):e7872.

52. Beppu F, Hosokawa M, Tanaka L, Kohno H, Tanaka T, Miyashita K: Potent inhibitory effect of trans9, trans 11 isomer of conjugated linoleic acid on the growth of human colon cancer cells. J Nutr Biochem 2006 17(12):830-836.

53. Kim YS, Cerbo RM, Hah CK, Bahn KN, Kim JO, Ha YL: Growth inhibition of osteosarcoma cell MG-63 by a mixture of trans, trans conjugated linoleic acid isomers: possible mechanistic actions. J Food Sci 2008, 73(1):T7-15.

54. De la Torre A, Debiton E, Durand D, Chardigny JM, Berdeaux O, Loreau O, Barthomeuf C, Bauchart D, Gruffat D: Conjugated linoleic acid isomers and their conjugated derivatives inhibit growth of human cancer cell lines. Anticancer Res 2005, 25(6B):3943-3949.

doi:10.1186/1476-511X-10-13

Cite this article as: Degen et al:: Influence of in vitro supplementation with lipids from conventional and Alpine milk on fatty acid distribution and cell growth of HT-29 cells. Lipids in Health and Disease 2011 10:131.

\section{Submit your next manuscript to BioMed Central and take full advantage of:}

- Convenient online submission

- Thorough peer review

- No space constraints or color figure charges

- Immediate publication on acceptance

- Inclusion in PubMed, CAS, Scopus and Google Scholar

- Research which is freely available for redistribution

Submit your manuscript at www.biomedcentral.com/submit 